GU J Sci, Part C, 6(2): 399-413 (2018)

Gazi Üniversitesi
Fen Bilimleri Dergisi
PART C: TASARIM VE TEKNOLOJI
dergipark.gov.tr/http-gujsc-gazi-edu-tr

\title{
Anortit Fazlı Seramiklere Bor Fosfat Katkısının Etkileri
}

\author{
Meltem ÇUBUK ${ }^{1 *}$, Metin GÜRÜ², Bülent BARAN ${ }^{3}$, Ali Sacid AĞIR ${ }^{4}$ \\ ${ }^{1}$ Ulaştırma, Denizcilik ve Haberleşme Bakanlığl, 06500, Çankaya/ANKARA \\ ${ }^{2}$ Gazi Üniversitesi, Mühendislik Fakültesi, Kimya Mühendisliği Bölümü, 06570, Çankaya/ANKARA \\ ${ }^{3}$ Gazi Üniversitesi, Fen Bilimleri Enstitüsü İleri Teknolojiler Anabilim Dall, 06500, Çankaya/ANKARA \\ ${ }^{4}$ Gazi Üniversitesi, Fen Bilimleri Enstitüsü Illeri Teknolojiler Anabilim Dall, 06500, Çankaya/ANKARA
}

\begin{abstract}
$\underline{\mathbf{O} z}$
Makale Bilgisi

Başvuru: 25/12/2017

Düzeltme: 20/02/2018

Kabul: 06/03/2018

Anahtar Kelimeler

Anortit

Bu çalışmada ısıl şoka dayanabilen seramik türü olarak anortit fazı seçilmiştir. İlk olarak bor fosfat sentezi gerçekleştirilmiş, elde edilen bor fosfat $1000^{\circ} \mathrm{C}$ 'da kalsine edilmiş, XRD ve kimyasal analizler ile karakterize edilmiştir. Diğer yandan faz diyagramında anortit fazını $\left(\mathrm{CaO}, \mathrm{Al}_{2} \mathrm{O}_{3}, \mathrm{SiO}_{2}\right)$ en çok kapsayan ve anortitin oluşabildiği en düşük sıcaklıktaki uygun ötektik noktalar seçilmiştir. Wollastonit, kaolinit ve kalsit kullanılarak 6 adet karışım hazırlanmıştır. Elde edilen 6 adet karışım iki kısma ayrılmış ve ikinci kısımlara \% 10 sentezlenen $\mathrm{BPO}_{4}$ ilavesi yapılmıştır. Karışımlar presle aynı basınçta şekillendirilmiş ve aynı koşullarda ve aynı ısıtma hızıyla elektrikli firında 1050, 1100, 1150 ve $1200^{\circ} \mathrm{C}$ 'da pişirilmiştir. Örneklere pişmeden önce DTA ve TGA analizleri, pişen örneklere ise XRD analizleri uygulanmıştır. Test sonuçlarına göre, sentezlenen $\mathrm{BPO}_{4}$ 'ın ilave edilmesi anortit fazlarının teorik oluşum sıcaklıklarından çok daha altındaki sıcaklıklarda şişme olmadan oluştuğunu göstermiştir.
\end{abstract}

$\mathrm{BPO}_{4}$

Isll sppk

Sivi faz sinterleşmesi

Ötektik

Keywords

Anorthite

$\mathrm{BPO}_{4}$

Thermal shock

Liquid phase sintering

Eutectic

\section{Effects of Boron Phosphate Additive on Ceramics with Anorthite Phase}

\begin{abstract}
In this study, the anorthite phase was chosen as a ceramic type that can withstand thermal shock. First, boron phosphate was synthesised, boron phosphate was calcined at $1000^{\circ} \mathrm{C}$ and characterized by XRD and chemical analyzes. On the other hand, in the phase diagram, the most suitable eutectic points covering the anorthite phase $\left(\mathrm{CaO}, \mathrm{Al}_{2} \mathrm{O}_{3}, \mathrm{SiO}_{2}\right)$ and at the lowest temperature at which anorthite can form are selected. 6 mixtures were prepared using wollastonite, kaolinite and calcite. The 6 mixtures prepared were separated into two equal parts and the second parts were added of $\mathrm{BPO}_{4} 10 \%$. The mixtures were pressed at the same pressure and cooked under the same conditions and at the same heating rate in the electric oven at $1050,1100,1150$ and $1200^{\circ} \mathrm{C}$. DTA and TGA analyzes were applied to the samples before sintering, and XRD analyzes were applied to the sintered samples. According to the test results, the addition of the synthesized $\mathrm{BPO}_{4}$ has shown that the anorthite phases are formed at temperatures well below the theoretical formation temperatures without swelling.
\end{abstract}

\section{GİRIŞ (INTRODUCTION)}

Seramik bir veya birden fazla metalin, metal olmayan element ile birleşmesi sonucu oluşan inorganik bileşikler olup, genellikle kayaların parçalanması ile oluşan kil, kaolen ve benzeri maddelerin yüksek sıcaklıkta pişirilmesi ile elde edilir. Klasik seramik üretiminde şekillendirilen yarı mamuller önce 22-24 saat bisküvi pişirimi ve daha sonra da 10-12 saat sırlı pişirimle firınlanarak elde edilmektedir. Bu kadar uzun süren pişirme işlemleri, seramik endüstrisinde çok fazla enerji tüketimine sebep olmaktadır. $\mathrm{Bu}$ nedenle son yıllarda gerçekleştirilen çalışmalar daha çok enerji sarfiyatını azaltacak yönlere kaymıştır. Seramikler çeşitli katkılar ile modifiye edilerek kürlenme sıcaklıkları düşürülmeye ve elektriksel özellikleri iyileştirilmeye çalışılmıştır [1]. 
Sentetik anortit hızlı pişirime uygunluğu ve daha düşük sıcaklıklarda üretilebildiğinden enerji sarfiyatını azaltacak niteliktedir [2]. Bu fazın oluşturulması ile yapılan seramikler klasik porseleni aratmayacak özelliktedir. Örneğin, klasik porselen üretiminde çok küçük ve ince mullit kristallerinin yerine çok ince ve küçük anortit kristalleri almıştır. Çok ince iğneler şeklindeki mullit kristalleri porselene dayanıklılık vermesi yanında sır ile seramiğin (masse) birbirine yapışmasını da sağlar. Ancak çok ince mullit kristallerinin oluşması, ortoklasın (potasyum feldispat) erime sıcaklığına yakın sıcaklıklarda belirli düzeyde gerçekleşmektedir. Bunun için daha yüksek sıcaklıklara çıkılması gerekmektedir. Daha homojen olarak daha düşük sıcaklıkta elde edilebilen anortit fazı ile yapılan porselenler ise mullit porselenlerini aratmayacak özeliklerde ve daha düşük sıcaklıkta oluşmaktadır [3]. Diğer bir deyişle daha ekonomiktir. Anortit kristalleri içeren porselenlerin bir diğer büyük avantajı da karışımda serbest kuvars olmadığından kuvarsın dönüşümleri sırasında ani hacim değişmelerinden dolayı çatlama riskinin olmamasıdır [4].

Anortit fazına dayalı porselenleşmiş camsı seramik üretimi son yıllarda yer karosu yapımında da önemi rol oynamaktadır [5]. Sertliğinin ve yoğunluğunun yüksek, su absorpsiyonunun \%0,5 den az, 1200$1230^{\circ} \mathrm{C}$ da sırlanmadan vitrifiye ve presle şekillenmeye uygun olması en büyük avantajlarıdır. Ayrıca, anortit seramikleri kendi kendini sırlama özelliğine sahiptir. Bu seramik endüstrisinde önemli olan iki pişirme işlemini bire indirme yanında sinterleme sıcaklık ve süresini olabildiğince düşürerek enerji tüketimini en aza indirmektir. Bu nedenle, hammadde karışımlarına ötektik veya peritektik bileşim veren borlu sırlar karıştırılmakta ve sıvı faz sinterleşmesi düşük sıcaklıkta denetimli olarak sağlanmaktadır. Klasik mullit porseleni yerine daha düşük sıcaklıkta çatlama riski olmaksızın anortit porseleni hızlı pişirimle elde edilebilmektedir.

Anortit fazının bileşimi $\left(\mathrm{CaO}, 2 \mathrm{Al}_{2} \mathrm{O}_{3}, 2 \mathrm{SiO}_{2}\right)$ ve $\left(\mathrm{CaO}, \mathrm{Al}_{2} \mathrm{O}_{3}, \mathrm{SiO}_{2}\right)$ olup, üçlü faz diyagramında bulunduğu bölge, ötektikler ve izotermler 2 boyutlu faz diyagramında gösterilmiştir (Şekil 1).

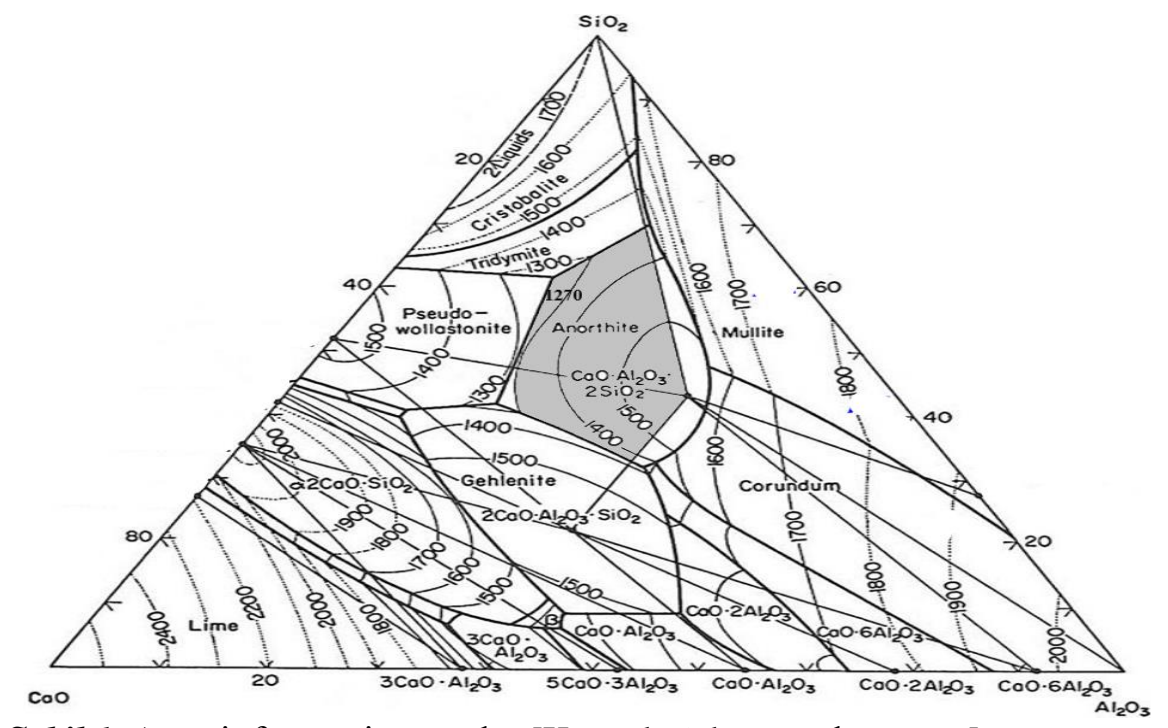

Şekil 1. Anortit fazı ve izotermler [Kaynak 6 dan uyarlanmışıtır].

Pişirilecek karışımlarda pişme sıcaklığını düşürmeye yönelik çalışmalar katkı maddelerinin ilaveleri ile yapılan modifikasyon çalışmalarıdır. Özellikle klasik seramik ürünlerinden olan mullite porseleni, alimuna esaslı yapılar ve kordierit üzerinde birçok çalışma yapılmıştır [3, 7, 8]. Bu seramikler sıvı faz sinterlemesi ile sinterleşmektedir. Mullit porseleni yerini daha düşük sıcaklıkta gelişebilen ve daha homojen yayılan anortit porselenin alması ve kordierite yapılan bazı katkılarla faz diyagramlarından elde edilen sıcaklıklardan daha düşük sıcaklıklarda elde edilmesi en dikkate değer çalışmalardır. Sinterleme sıcaklığını düşürmede bazı bor türevlerinin kullanılması üzerinde çalışmalar yapılmıştır [7].

$\mathrm{Bu}$ çalışmada öncelikle bileşimlerde kullanmak üzere laboratuar koşullarında $\mathrm{BPO}_{4}$ üretilmiştir. $\mathrm{BPO}_{4}$ üretiminde borik asit ve fosforik asit başlangıç maddesi olarak seçilmiştir. Anortit fazın oluşması için gerekli hammadde seçimi ve hammaddelerin miktarlarının hesaplanması yapılmış ve karışımlar belirlenen oranlarda hazırlanmıştır. Hazırlanan karışımlar kütlece ikiye ayrılmış ve ikinci kısımlarına $\% 10 \mathrm{BPO}_{4}$ 
ilavesi yapılmıştır. Karışımlar presle aynı basınçta şekillendirilmiştir. $\mathrm{BPO}_{4}$ ilavesiz ve $\mathrm{BPO}_{4}$ ilaveli tüm örnekler aynı koşullarda $1050,1100,1150,1200^{\circ} \mathrm{C}$ sıcaklıklara toplam 3 saatlik bir 1sıtma rejimiyle pişirilmiştir. Elde edilen örneklere DTA, TGA, XRD analizi uygulanmıştır.

\section{MATERYAL VE METOT (MATERIAL AND METHOD) \\ 2.1 Faz Diyagramından Anortit Karışımlarının Belirlenmesi (Determination of Anorthite Mixtures from Phase Diagram)}

Bileşimler faz diyagramından okunarak anortit fazının oluşması için wollastonite, kaolinit kalsit, alumina, kuartz kullanılmıştır. Hesaplanan karışımlar bilyeli değirmende kuru kuruya karıştırılmıştır. Homojen hale gelen karışımlar ikiye ayrılmış ve ikincisi kısımlarına \%10 bor fosfat $\left(\mathrm{BPO}_{4}\right)$ ilavesi yapılmıştır. Bor fosfat katk11 anortit karışımları (AP1, AP2, AP3, AP4, AP5, AP6) preste 50x20 mm boyutunda dikdörtgenler prizması şeklinde $5 \mathrm{kgp} / \mathrm{cm}^{2}$ basınçla şekillendirilmiştir.

Anortit bölgesinde en düşük ötektik veren 6 nokta seçilmiştir. Anortit fazının oluşması için wollastonit, kaolinit mineralleri, kalsit, alumina ve kuartz hammaddeleri kullanılarak miktarları hesaplanmış ve karışımlar oluşturulmuştur. Aynı karışımlar bir defa daha \% $10 \quad \mathrm{BPO}_{4}$ katkısı ile hazırlanmıştır. Karışımlara DTA, TGA analizleri yapılmıştır. Presle şekillendirilen örneklere XRD analizi yapılmıştır. Anortit karışımları için seçilen noktalar Şekil 2'de verilmiştir.

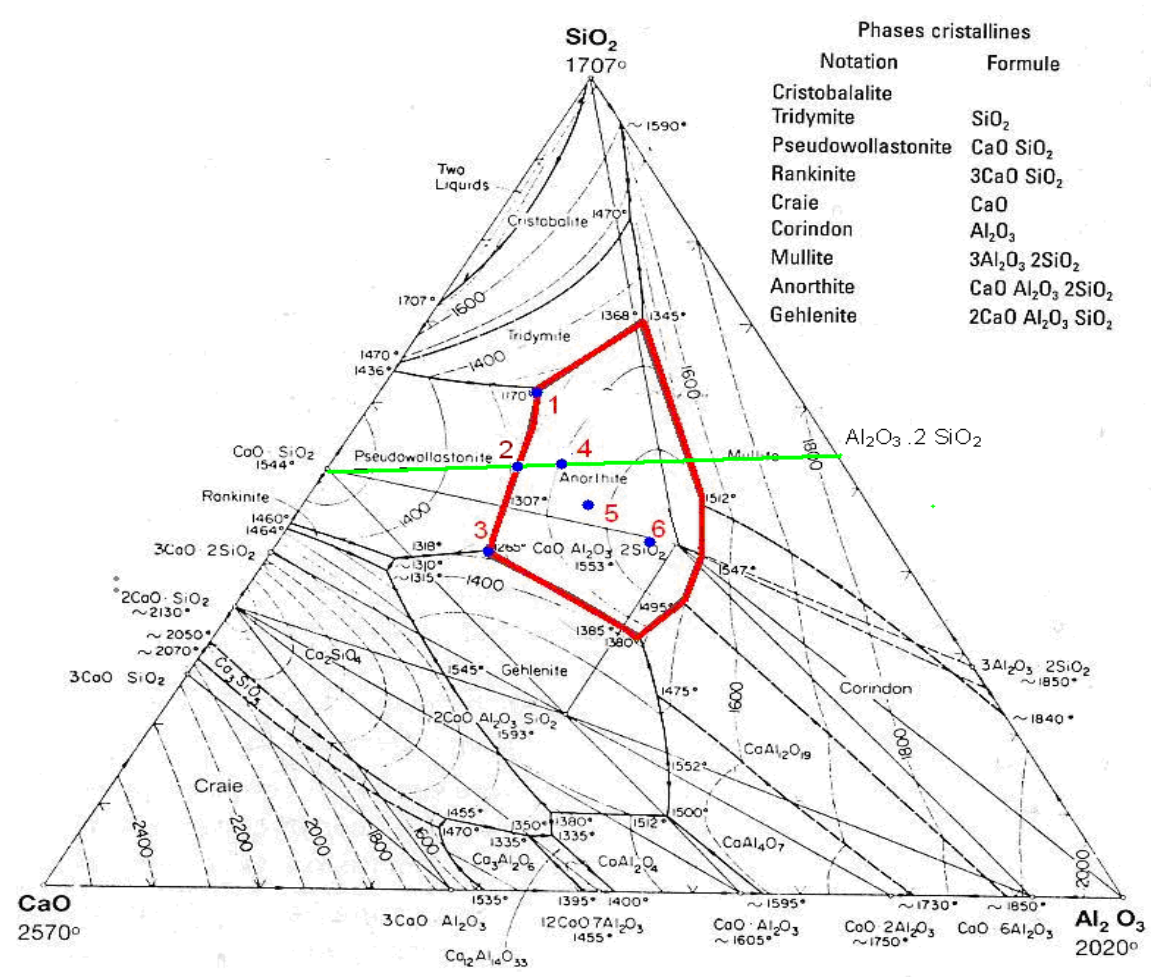

Şekil 2. Faz diyagramında anortit elde etmek için anortit bölgesinde seçilen noktalar [Kaynak 6 dan uyarlanmıştır].

Faz Diyagramından Anortit Karışımlarının Belirlenmesi İçin Örnek hesaplama:

$\mathrm{CaO}, \mathrm{Al}_{2} \mathrm{O}_{3}, \mathrm{SiO}_{2}$ faz diyagramında 1 nolu noktanın bileşimini bulabilmek için $\mathrm{CaO} \mathrm{SiO}_{2}$ 'in bulunduğu nokta wollastonit ve $\mathrm{Al}_{2} \mathrm{O}_{3}$. $2 \mathrm{SiO}_{2}$ 'ün bulunduğu nokta da kaolinit olarak işaretlenir (Şekil 3). Kaolin, wollastonit ve $\mathrm{SiO}_{2}$ 'den oluşan üçgen çizilir. $\mathrm{Bu}$ üçgenin içerisinde bulunan 1 nolu noktadan köşelere doğrular çizilir. 1 ile kaolinit doğrusunun uzantısı wollastonit ve $\mathrm{SiO}_{2}$ kenarını kestiği nokta 1'; 1 ile wollastonitin doğrusunun uzatıldığ 1 doğrunun kaolin ve $\mathrm{SiO}_{2}$ kenarını kestiği nokta 3' ve 1 ile $\mathrm{SiO}_{2}$ doğrusunun wollastonit kaolinit doğrusunu kestiği noktada 2' olarak işaretlenir. 


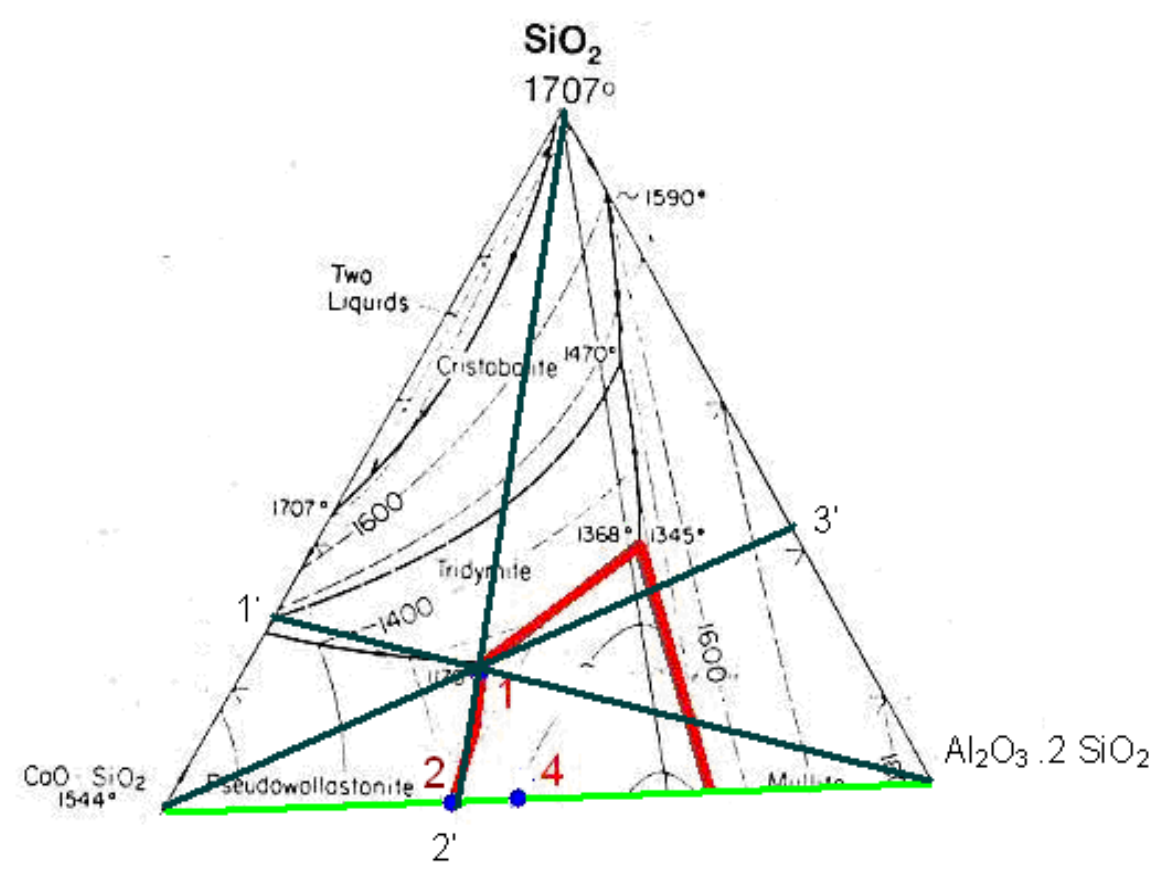

Şekil 3. Faz diyagraminda 1 numaralı numunenin hesaplanması

$1-1$ ' $/ 1$-Kaolin $=21 \mathrm{~mm} / 70 \mathrm{~mm}=0,31 \rightarrow \% 30$

$1-2{ }^{\prime} / 2-\mathrm{SiO}_{2}=14 \mathrm{~mm} / 69 \mathrm{~mm}=0,203 \rightarrow \% 20$

$1-3^{\prime} / 3^{\prime}$-Wollastonit $=35 \mathrm{~mm} / 70 \mathrm{~mm}=0,50 \rightarrow \% 50$

olarak ölçülür. Böylece 1 nolu noktanın bileşimi \% 30 kaolin, \% 20 kuartz ve $\% 50$ wollastonit olarak hesaplanır. Benzer hesaplamalar diğer noktalar için yapılmış ve Tablo 1'de verilmiştir.

Tablo 1. Anortit karışımları için kullanılan hammadde miktarları.

\begin{tabular}{|l|l|l|l|l|l|l|}
\hline $\begin{array}{l}\text { Numune } \\
\text { No }\end{array}$ & Wolastonit \% & Kaolin \% & $\mathrm{Al}_{2} \mathrm{O}_{3} \%$ & Kalsit \% & $\mathrm{SiO}_{2} \%$ & $\mathrm{BPO}_{4} \%$ \\
\hline A 1 & 50 & 30 & - & - & 20 & - \\
\hline A 2 & 62 & 38 & - & - & - & - \\
\hline A 3 & 34,1 & 44 & - & 21,7 & - & - \\
\hline A 4 & 54,6 & 45,6 & - & - & - & - \\
\hline A 5 & 55,8 & 34,2 & 10 & - & - & - \\
\hline A 6 & 49,6 & 30,4 & 20 & - & - & - \\
\hline A 1 P & 50 & 30 & - & - & 20 & 10 \\
\hline A 2 P & 62 & 38 & - & - & - & 10 \\
\hline A 3 P & 34,1 & 44 & - & 21,7 & - & 10 \\
\hline A 4 P & 54,6 & 45,6 & - & - & - & 10 \\
\hline A 5 P & 55,8 & 34,2 & 10 & - & - & 10 \\
\hline A 6 P & 49,6 & 30,4 & 20 & - & - & 10 \\
\hline
\end{tabular}

\section{2. $\mathrm{BPO}_{4}$ 'In elde edilmesi (To Obtain $\mathrm{BPO}_{4}$ )}

$\mathrm{Bu}$ çalışmada kullanılan $\mathrm{BPO}_{4}$ aşağıdaki tepkimeye göre stokiyometrik oranlar kullanılarak elde edilmiştir. 
$\mathrm{H}_{3} \mathrm{BO}_{3}+\mathrm{H}_{3} \mathrm{PO}_{4} \longrightarrow \mathrm{BPO}_{4}+3 \mathrm{H}_{2} \mathrm{O}$

$(61,81 \mathrm{gr}) \quad(97,97 \mathrm{gr}) \quad(105,78 \mathrm{gr}) \quad(54 \mathrm{gr})$

$\mathrm{Bu}$ tepkimeyi gerçekleştirmek için \%99'luk $\mathrm{H}_{3} \mathrm{BO}_{4}$ kullanılmıştır. Bir beher içerisine konulan fosforik asit üzerine 61,81 gr borik asit pervaneli karıştırıcıda yavaş yavaş ilave edilmiştir. Elde edilen beyaz renkli karışım 2 saat süreyle sürekli karıştırılmıştır. Karışım daha sonra 1sıtıcıda yavaş yavaş 1sıtılmış ve giderek viskozitesi artan bir sıvı haline getirilmiştir. Oluşan bu viskoz sıvı bir çeker ocakta kuruyana kadar 1sıtılmış ve oluşan suyun büyük bir bölümünün uçurulması sağlanmıştır. Elde edilen beyaz renkli katı daha sonra bir porselen havanda öğütülmüştür. Öğütülen katı sırsız şamot kaplara mümkün olduğu kadar geniş yüzeyler oluşturacak şekilde konularak elektrikli fırında $1000^{\circ} \mathrm{C}$ da iyi havalanan bir çeker ocakta 1 saat süre bekletilerek kalsine edilmiştir. Elde edilen sert beyaz katı seramik, hazneli bilyalı değirmende (Planetary ball mill) tekrar öğütülmüştür ve deneylerde kullanılıncaya kadar ağzı sıkıca kapatılarak saklanmıştır.

\subsection{Karışımların Pişirilmesi (Cooking of Mixtures)}

Karışımlar Protherm marka SiC 1sıtma elemanlı elektrikli fırında pişirilmiştir. Pişirme işlemi sırasında kullanılan SiC firın raflarına erime ve yapışma olmaması için kuartz serpilmiştir. Pişirme işlemi ısıtma ve soğutma dâhil 3 saat sürmüştür. Fırın maksimum sıcaklığa çıkarıldıktan sonra 30 dakika maksimum sıcaklıkta bekletilmiştir ve sonra kendi doğal soğumasına terk edilmiştir. Karışımlar; 1050, 1100, 1150, $1200^{\circ} \mathrm{C}$ 'lara pişirilmiştir.

\subsection{DTA ve TG Analizi (DTA and TG Analysis)}

Karışımlar 1sıl analizlere tabi tutulmuştur. Diferansiyel termik analiz (DTA) ve 1sıl gravimetrik (TGA) analiz DuPond marka, Seteram 1750 model cihazla yapılmıştır. Karışımlar pişirilmeden önce belirli tane iriliğine 100 mesh $(0,147 \mathrm{~mm})$ ögütülmüştür. DTA ve TGA analizlerinde firının 1 sıtma hız $13,6^{\circ} \mathrm{C} / \mathrm{saat}$ olarak ayarlanmıştır. Isıl analizlerde maksimum $1100^{\circ} \mathrm{C}$ sıcaklığa çıkılabilmiştir.

\subsection{XRD Analizi (XRD Analysis)}

Karışımlar pişirildikten sonra agat havanda tekrar 100 mesh $(0,147 \mathrm{~mm})$ öğütülmüştür. Philips marka, $\mathrm{CuK} \alpha 1 \lambda$ 1.541874, XRD cihazı ile X ışını kırınımı desenleri elde edilmiş ve XRD desenleri ASTM standart kartlarından elde edilen verilerle karşılaştırılmıştır.

\subsection{Materyaller (Materials)}

Anortit bileşimlerde kullanılan hammaddelerin kimyasal analizleri Tablo 2'de verilmiştir.

Tablo 2. Anortit fazlarını elde etmede kullanılan hammaddelerin kimyasal analizleri.

\begin{tabular}{|l|l|l|l|l|l|}
\hline $\begin{array}{l}\text { Kimyasal Analiz } \\
\%\end{array}$ & Kaolen & Vollastonit & Kuvars & Alumina & Talk \\
\hline $\mathrm{SiO}_{2}$ & 47 & 49 & 99,1 & 0.03 & 63 \\
\hline $\mathrm{AI}_{2} \mathrm{O}_{3}$ & 37 & & 0,2 & 98.5 & 0,4 \\
\hline $\mathrm{Fe}_{2} \mathrm{O}_{3}$ & 0,45 & 0,35 & 0,1 & 0.035 & 0,25 \\
\hline $\mathrm{TiO}_{2}$ & 0,50 & & & & \\
\hline $\mathrm{CaO}$ & 0,30 & 43 & 0,2 & & 0,4 \\
\hline $\mathrm{MgO}$ & 0,20 & & 0,1 & & 30 \\
\hline $\mathrm{K}_{2} \mathrm{O}$ & 0,80 & & 0,2 & & 0,04 \\
\hline $\mathrm{Na}_{2} \mathrm{O}$ & 0,20 & & 0,1 & 0.5 & 0,08 \\
\hline $\mathrm{P}_{2} \mathrm{O}_{5}$ & & & & & 0,06 \\
\hline $\mathrm{H}_{2} \mathrm{O}$ & & & & & 0,05 \\
\hline $\mathrm{A} . \mathrm{Z}$. & 12 & 1,5 & 1,5 & 1 max & 4,78 \\
\hline
\end{tabular}




\section{SONUÇLAR VE TARTIŞMA (RESULTS AND DISCUSSION)}

Kalsinasyondan evvel ve kalsinasyondan sonra elde edilen $\mathrm{BPO}_{4}{ }^{\prime} 1$ n kimyasal analiz sonuçları ile teorik $\mathrm{BPO}_{4}{ }^{\prime}$ 'n, $\% \mathrm{~B}_{2} \mathrm{O}_{3}$ ve $\% \mathrm{P}_{2} \mathrm{O}_{5}$ miktarları Tablo 3'de gösterilmiştir.

Tablo 3. $\mathrm{BPO}_{4}$ teorik ve deneysel kimyasal analiz sonuçları.

\begin{tabular}{|l|l|l|l|l|}
\hline & $\% \mathrm{~B}_{2} \mathrm{O}_{3}$ & $\% \mathrm{P}_{2} \mathrm{O}_{5}$ & $\%$ Kıdırma kaybı & Toplam \\
\hline $\mathrm{BPO}_{4}$ (Teorik) & 32,9 & 68,1 & 0,0 & 100,0 \\
\hline $\mathrm{BPO}_{4}$ (Kalsine) & 40,76 & 58,90 & 0,28 & 99,94 \\
\hline $\mathrm{BPO}_{4}$ (Kalsine Edilmemiş) & 30,58 & 39,34 & 30,05 & 99,97 \\
\hline
\end{tabular}

$2 \mathrm{BPO}_{4} \longrightarrow \mathrm{B}_{2} \mathrm{O}_{3}+\mathrm{P}_{2} \mathrm{O}_{5}$

$\% 32,9 \% 68,1$

Kalsine edilmiş ve kalsine edilmemiş $\mathrm{BPO}_{4}$ 'ın XRD desenleri Şekil 4 (a) ve (b)'de verilmektedir.
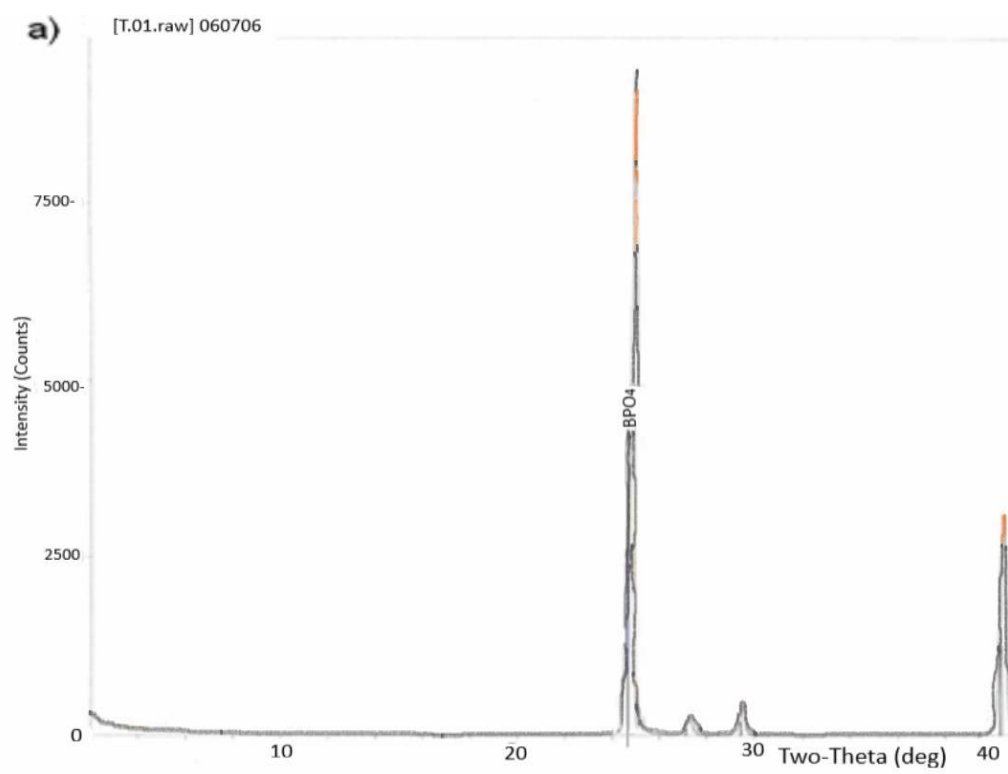

[D1-074-1169> BPOs-Boron Phosphate

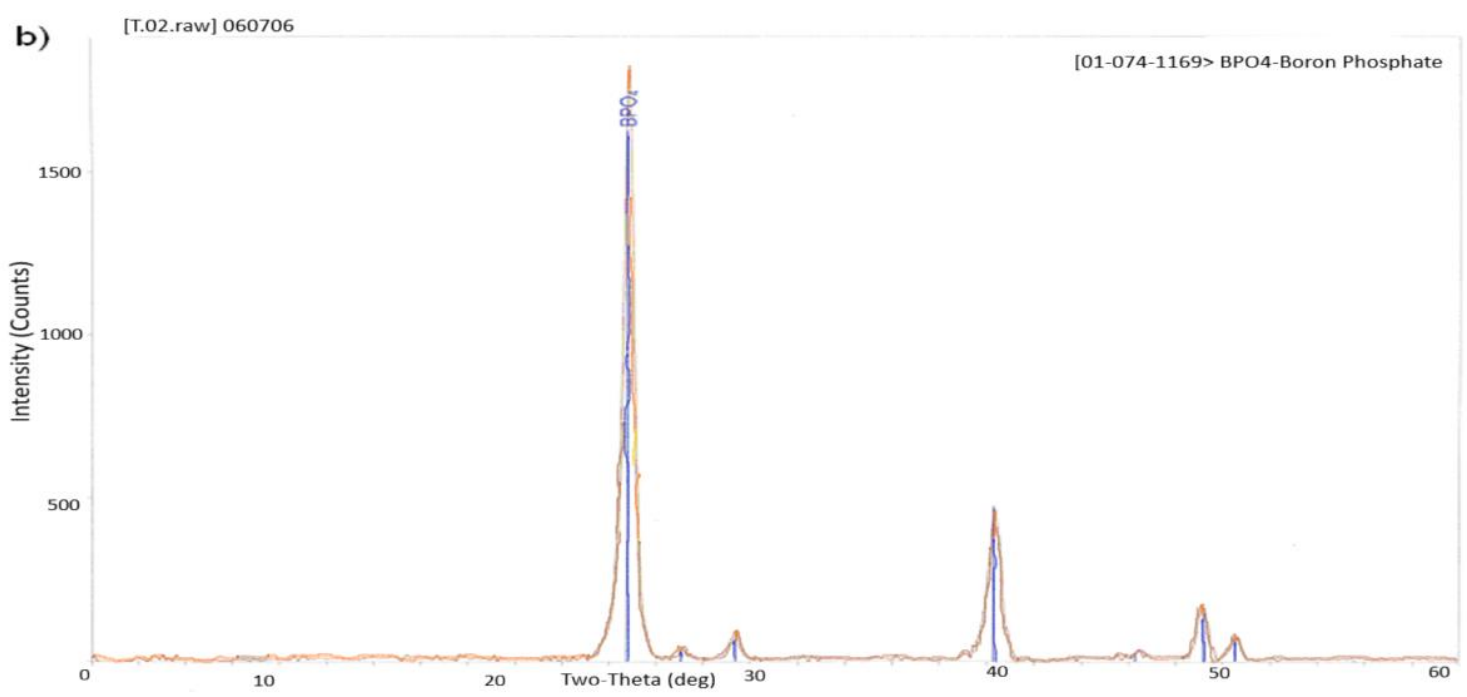

Şekil 4. $\mathrm{BPO}_{4}$ 'ın XRD desenleri (a) Kalsine edilmiş (b) Kalsine edilmemiş. 
Tablo 4. $\mathrm{BPO}_{4}$ 'ın ASTM standart değerleri

\begin{tabular}{|c|c|c|c|c|c|c|c|}
\hline $\mathrm{d}$ & 3,63 & 2,25 & 1,86 & 3,63 & \multirow{2}{*}{\multicolumn{3}{|c|}{$\begin{array}{l}\mathrm{BPO}_{4} \\
\text { BORON FOSFAT }^{2}\end{array}$}} \\
\hline $\mathrm{I} / \mathrm{I}_{\mathrm{O}}$ & 100 & 30 & 8 & 100 & & & \\
\hline \multicolumn{5}{|c|}{$\begin{array}{l}\text { Rad CuK } \alpha 1 \lambda 1,5405 \\
\text { Cut off } 50 \text { A Ref.De } \\
\text { Wolff,Techn.Phys.Dienst,Delft,Holland. }\end{array}$} & $\mathrm{d}^{\circ} \mathrm{A}$ & $\mathrm{I} / \mathrm{I}_{\mathrm{O}}$ & hkl \\
\hline \multirow{18}{*}{\multicolumn{5}{|c|}{ Sys.Tetragonal }} & 3,632 & 100 & 101 \\
\hline & & & & & 3,322 & 4 & 002 \\
\hline & & & & & 3,067 & 4 & 110 \\
\hline & & & & & 2,254 & 30 & 112 \\
\hline & & & & & 1,973 & 2 & 103 \\
\hline & & & & & 1,852 & 8 & 211 \\
\hline & & & & & 1,816 & 4 & 202 \\
\hline & & & & & 1,661 & 1 & 004 \\
\hline & & & & & 1,534 & 2 & 220 \\
\hline & & & & & 1,460 & 8 & 114,213 \\
\hline & & & & & 1,413 & 1 & 301 \\
\hline & & & & & 1,393 & 1 & 222 \\
\hline & & & & & 1,372 & 2 & 310 \\
\hline & & & & & 1,319 & 4 & 204 \\
\hline & & & & & 1,271 & 1 & 105 \\
\hline & & & & & 1,268 & 2 & 312 \\
\hline & & & & & 1,211 & 2 & 303 \\
\hline & & & & & 1,184 & 2 & 321 \\
\hline
\end{tabular}

$\mathrm{Bu}$ sonuçlara göre $\mathrm{BPO}_{4}{ }^{\prime}$ 'n $\mathrm{ASTM}$ standart $\mathrm{d}$ ve $\mathrm{I} / \mathrm{I}_{\mathrm{O}}$ değerleri ile kıyaslandığında büyük bir uyuşum içerisinde olduğu görülmüştür. Kimyasal analizde beklenen $\% \mathrm{~B}_{2} \mathrm{O}_{3}(\% 40,76)$ stokiyometrik olarak hesaplanandan $(\% 32,9)$ daha yüksek bulunmuştur. XRD cihazı ile elde edilen X ışını kırınımı desenleri ASTM standart kartlarından (Tablo 4) elde edilen verilerle karşılaştırılmıştır (Şekil 5). 2O, d ve I/Io değerleri ise Tablo 5'de verilmiştir.

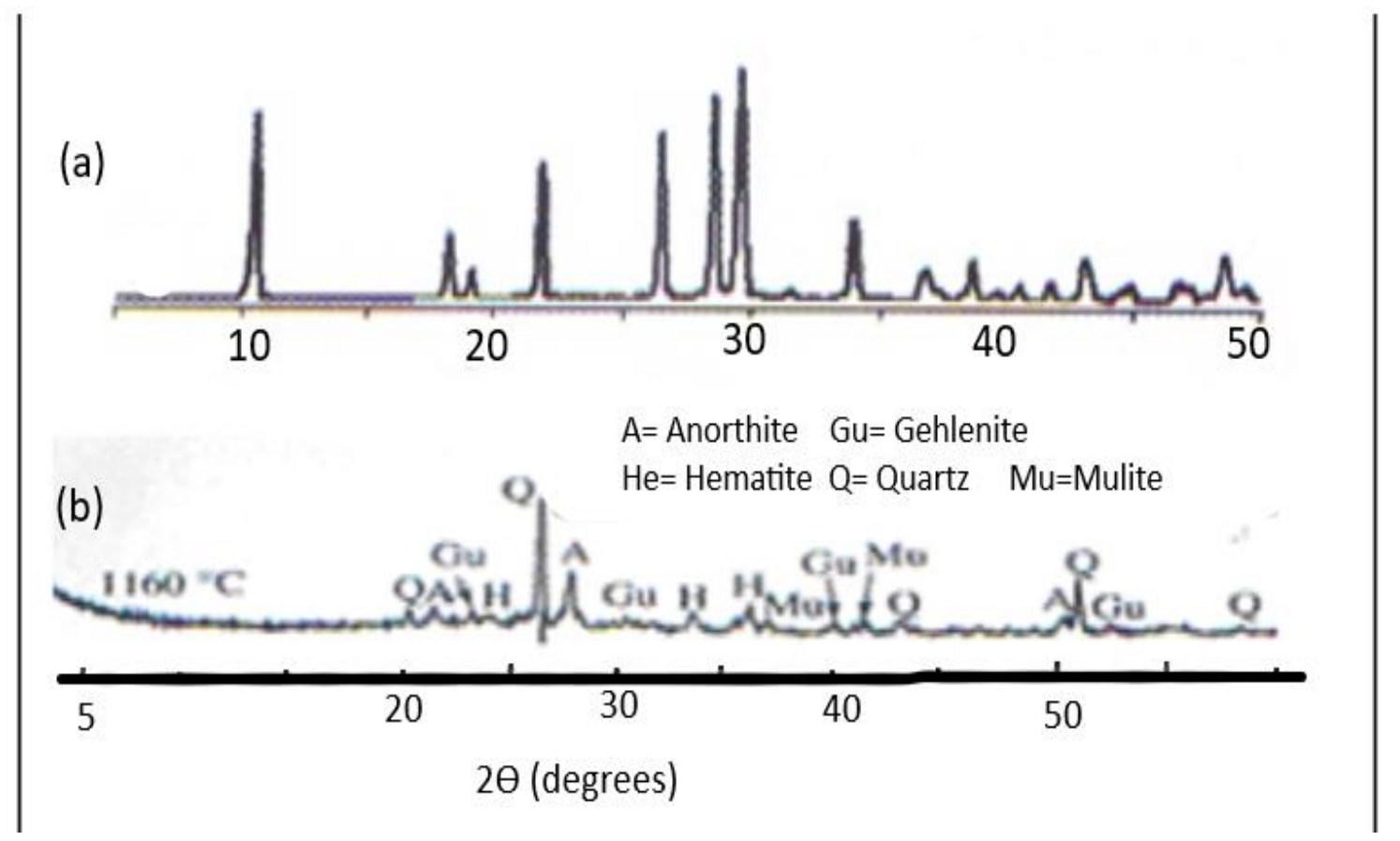

Şekil 5. Anortit piklerinin faz diyagramlarındaki yeri, (a) 1 saat $1350^{\circ} \mathrm{C}$ 'da pişirilen anortit X-Işııı kırınımı deseni, (b) Anortitin X-Işını Kırınımı Deseni [Kaynak 6 dan uyarlanmıştır]. 
Tablo 5. Anortitin $2 \theta$ ve I/Io değerleri

\begin{tabular}{|l|l|l|l|l|l|l|}
\hline $2 \Theta$ & 28,03 & 27,88 & 28,58 & 21,98 & 27,76 & 2733 \\
\hline I/Io & 75 & 100 & 45 & 60 & 35 & 58 \\
\hline
\end{tabular}

$\mathrm{BPO}_{4}$ ilave edilmemiş anortit karışımlarının DTA ve TG eğrileri Şekil 6 (a), (b), (c), (d), (e), (f)'de $\mathrm{BPO}_{4}$ ilave edilmiş anortit karışımlarının DTA ve TG eğrileri Şekil 7 (a), (b), (c), (d), (e), (f)'de gösterilmiştir.

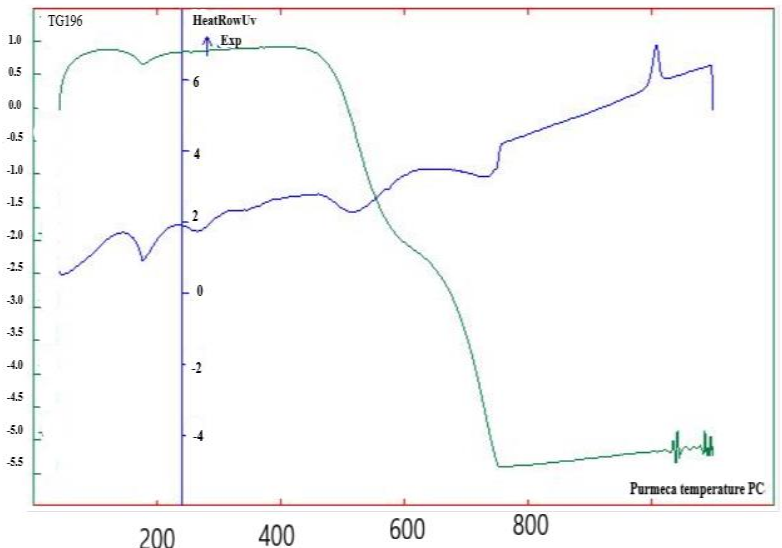

(a)

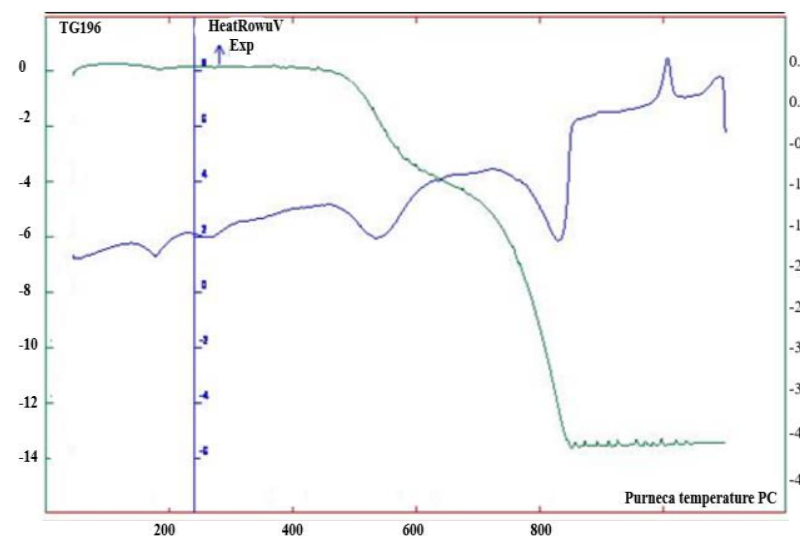

(c)

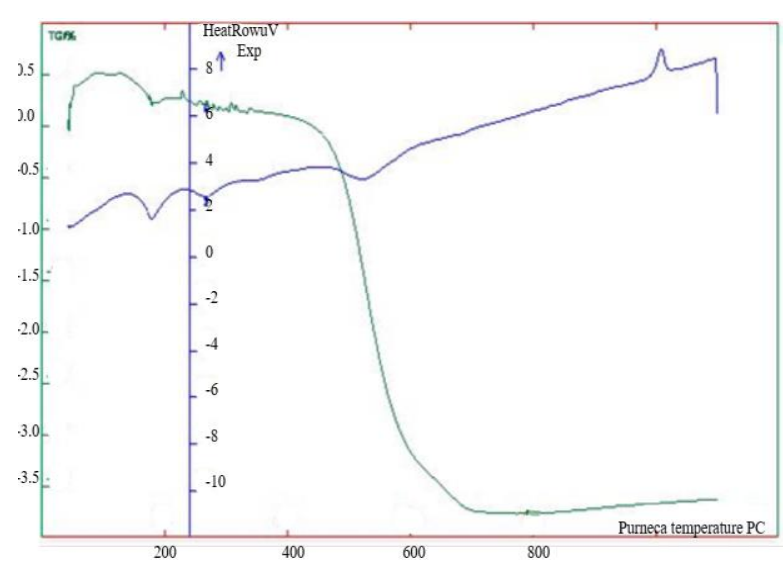

(e)

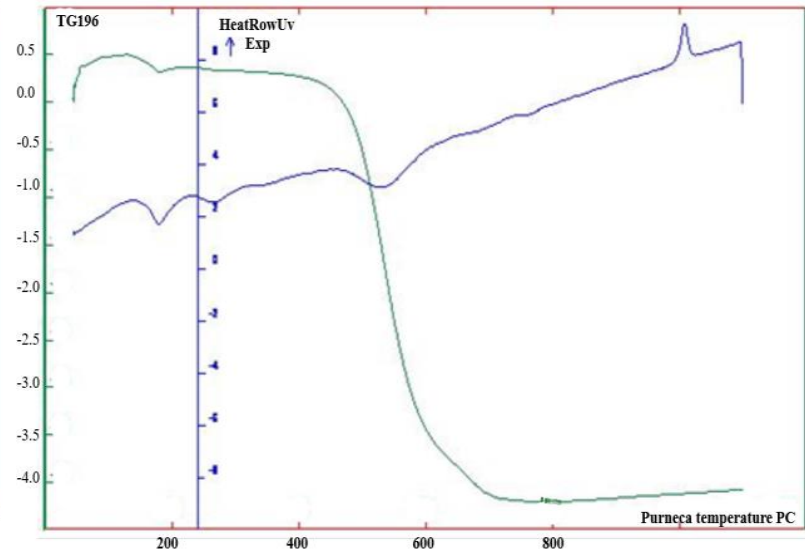

(b)

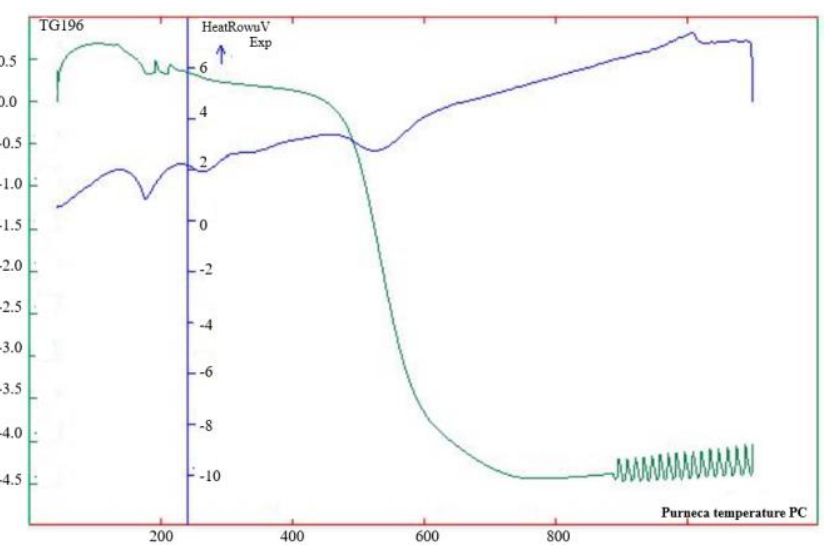

(d)

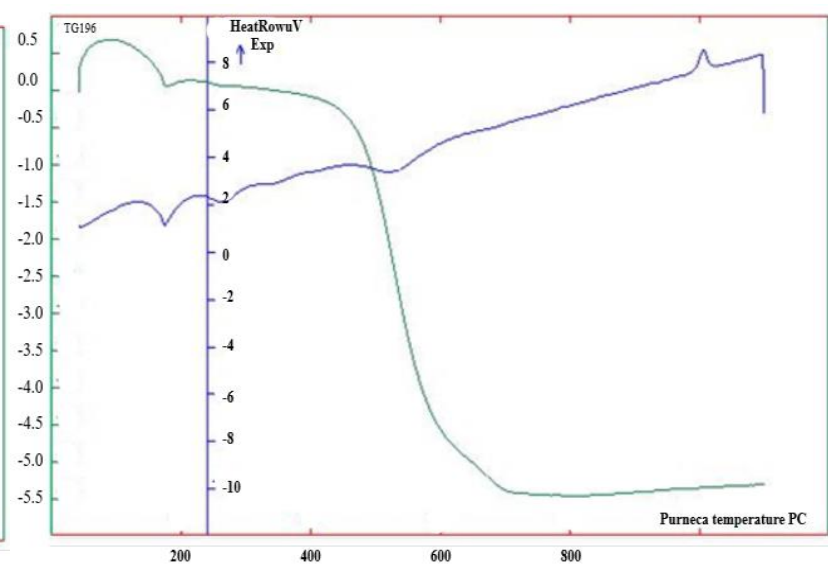

(f)

Şekil 6. $\mathrm{BPO}_{4}$ 'sız anortit karışımlarının (a-A1, b-A2, c-A3, d-A4, e-A5, $f$-A6) DTA ve TG analiz eğrileri. 


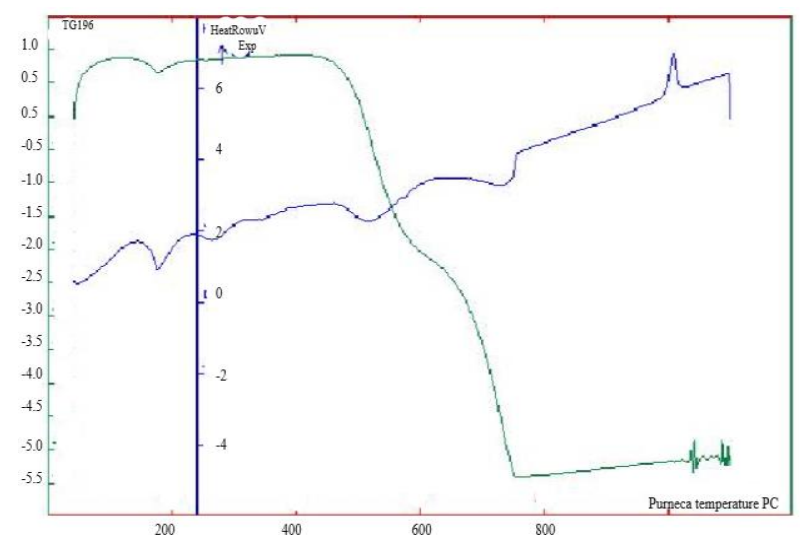

(a)

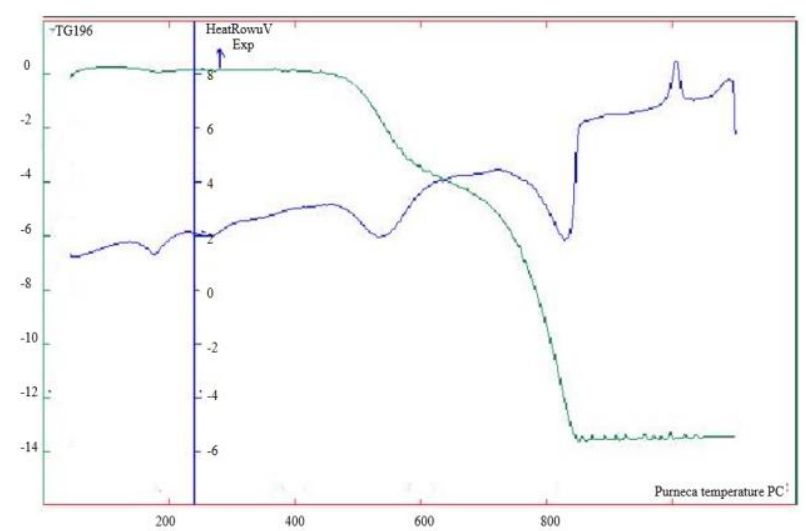

(c)

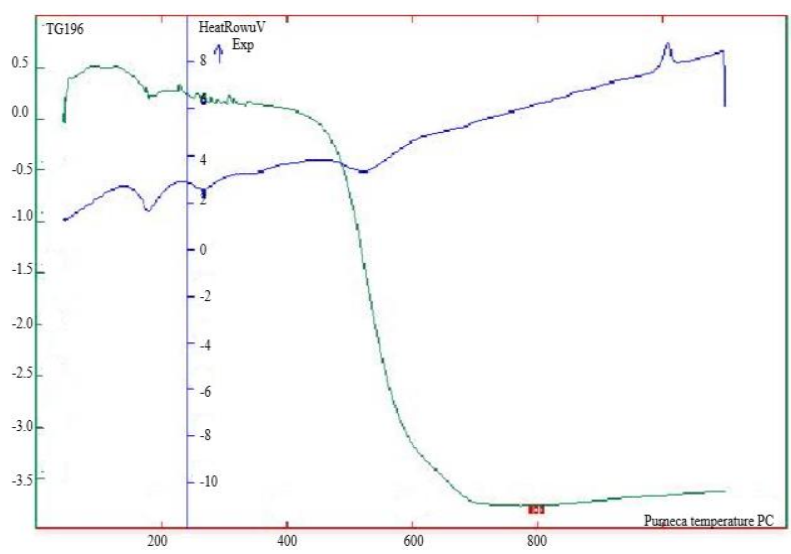

(e)

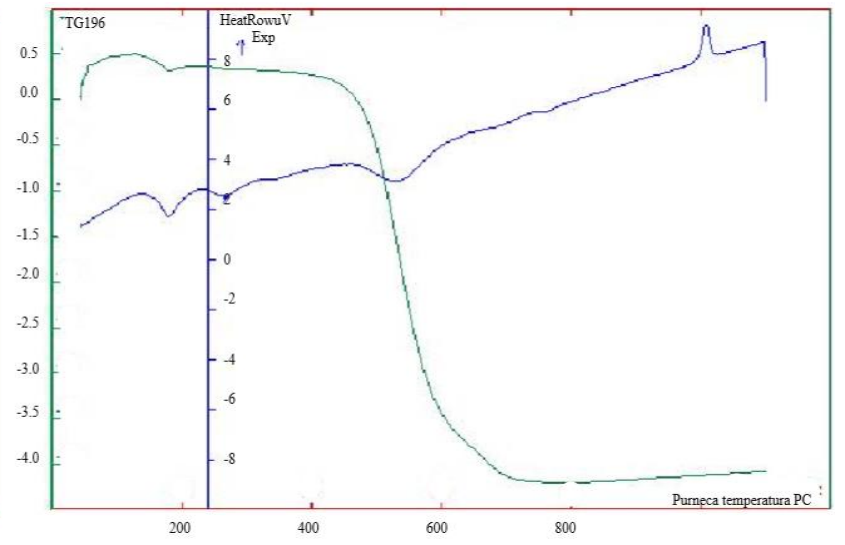

(b)

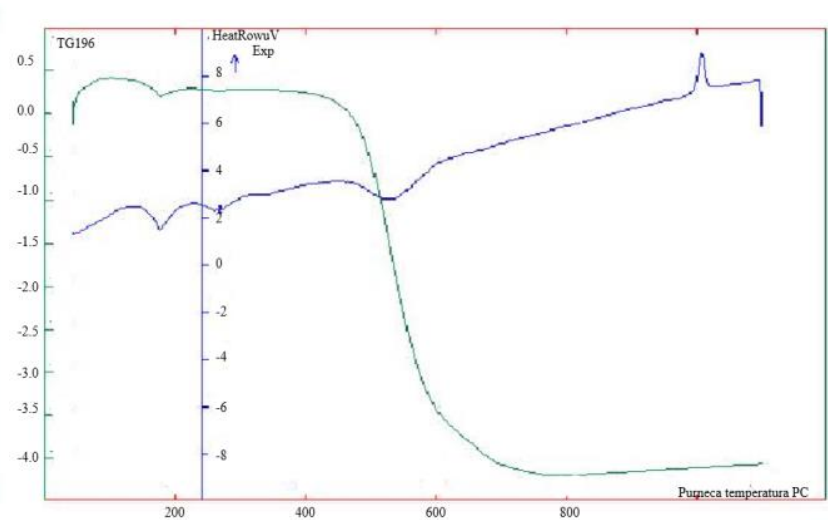

(d)

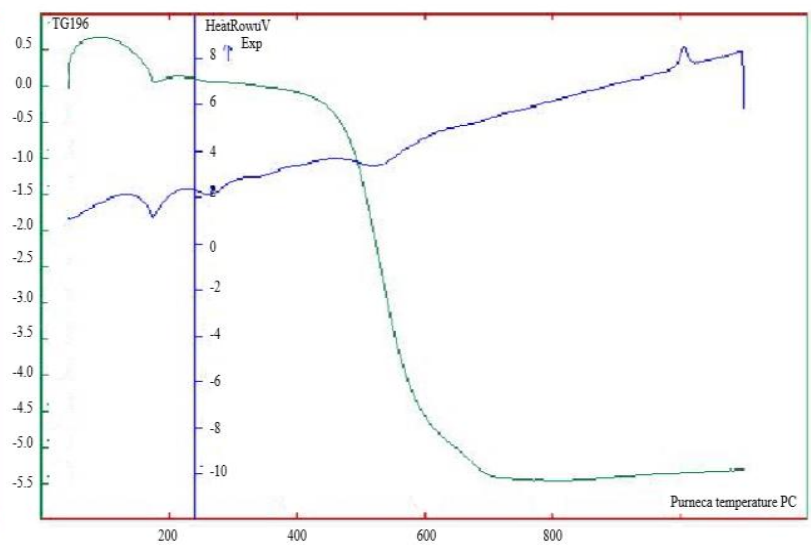

(f)

Şekil 7. $\mathrm{BPO}_{4}$ 'lı anorthit karışımının (a-A1, b-A2, c-A3, d-A4, e-A5, $f$-A6) DTA ve TGA analiz eğrileri.

İlk endotermik pik $175^{\circ} \mathrm{C}$ da başlayıp $220^{\circ} \mathrm{C}$ 'da bitmiş ve en şiddetli değerine $200^{\circ} \mathrm{C}$ 'de ulaşmıştır. $\mathrm{Bu}$ hammaddelerdeki hidroksitlerin uzaklaşma tepkimesidir. İkinci endotermik pik $500^{\circ} \mathrm{C}$ 'da başlamış $650^{\circ} \mathrm{C}$ 'da bitmiş en şiddetli değerine $600^{\circ} \mathrm{C}$ 'da ulaşmıştır. Bu tepkime sırasında çok büyük kütle kaybının olduğu TGA eğrisinden görülmektedir. $\mathrm{Bu}$ pik kaolinin meta kaoline dönüşüm tepkimesidir. Üçüncü endotermik pik $700^{\circ} \mathrm{C}$ 'da başlamış $800^{\circ} \mathrm{C}$ 'da bitmiş ve en şiddetli değerine $775^{\circ} \mathrm{C}$ ulaşmıştır. $\mathrm{Bu}$ wollastonit içerisindeki $\mathrm{CaCO}_{3}$ safsızlığından meydana gelen bir piktir. Kalsit kalsinasyona uğramakta ve $\mathrm{CaO}$ haline dönüşmektedir. $1020^{\circ} \mathrm{C}$ 'da meydana gelen ekzotermik pik mullitin fazının oluşum tepkimesinden kaynaklanmaktadır. Burada $1025-1050^{\circ} \mathrm{C}$ 'larda çıkması beklenen ekzotermik anortit piki

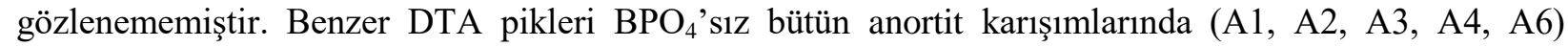
görülmüş̧ür. Sadece 
A3 nolu örnekte $1025^{\circ} \mathrm{C}$ 'da yukarı doğru bir pik başlangıcı gözlenmiştir. Bu anortit oluşumunun ilk işaretleridir. Ancak pik tam oluşmadığından tepkime tam görülememiştir.

DTA pikleri $\mathrm{BPO}_{4}{ }^{\prime}$ lı bütün anortit karışımlarında (AP1, AP2, AP3, AP4, AP5, AP6 ) da görülmüştür. Ancak maksimum sıcaklıkta meydana gelen çok geniş ve belli belirsiz pikler $1025^{\circ} \mathrm{C}$ 'da düzleşmeyle kendini göstermiştir. Bu anortit fazının oluştuğunu göstermektedir. DTA'nın hassasiyeti ve isıtma hızı bu ekzotermik pikin görünürlügünü etkilemektedir.

$\mathrm{BPO}_{4}$ 'sız ve $\mathrm{BPO}_{4}{ }^{\prime} l 1$ anortit karışımlarının X-Işını Kırınımı Analizi Eğrileri Şekil 8-19 arasında verilmiştir. Şekillerde kırmızı pikler bor-fosfatsız, mavi pikler bor-fosfatlı anortit piklerini göstermektedir.

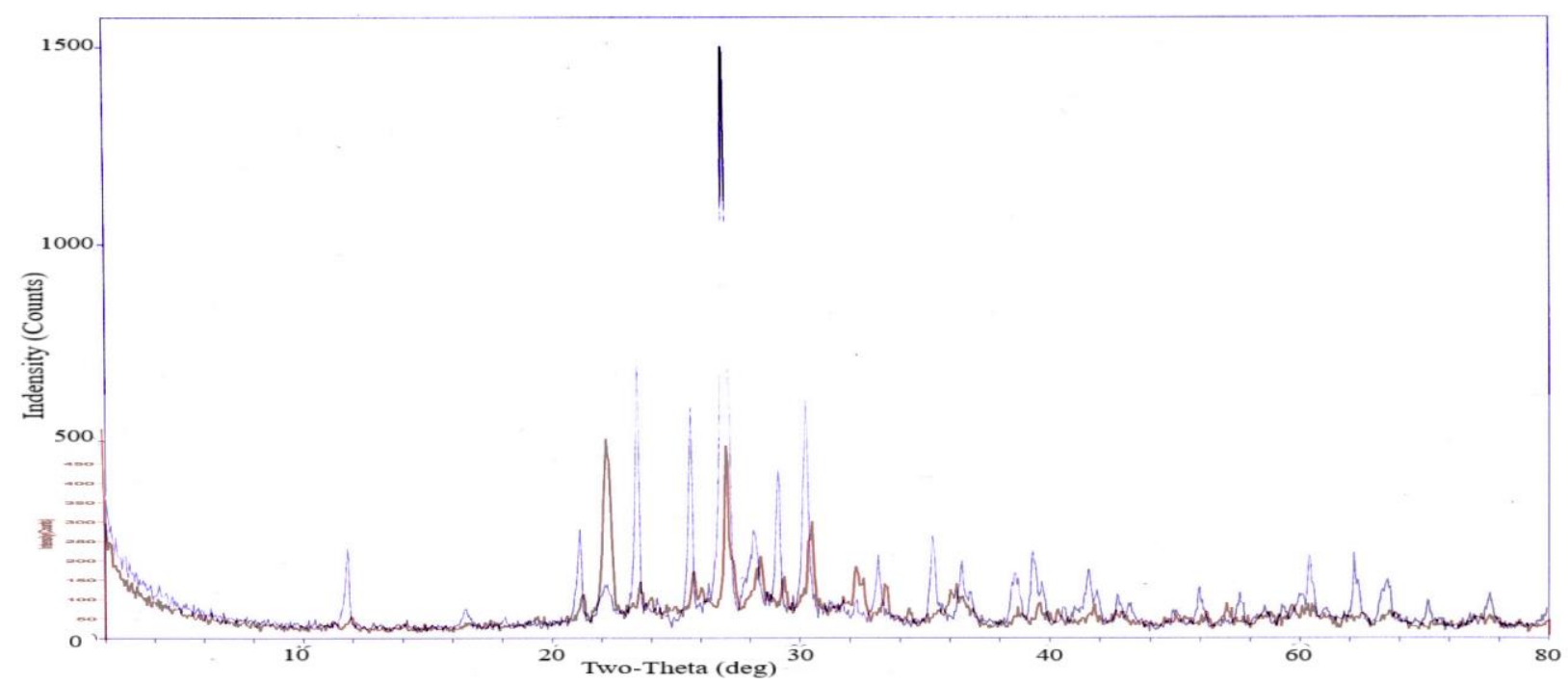

Şekil 8. $1100^{\circ} \mathrm{C}$ 'de sinterlenmiş $\mathrm{Al}$ karlşımının $\mathrm{BPO}_{4}$ katkılı ve katkısız XRD kırınım desenlerinin karşılaş̧tırılması.

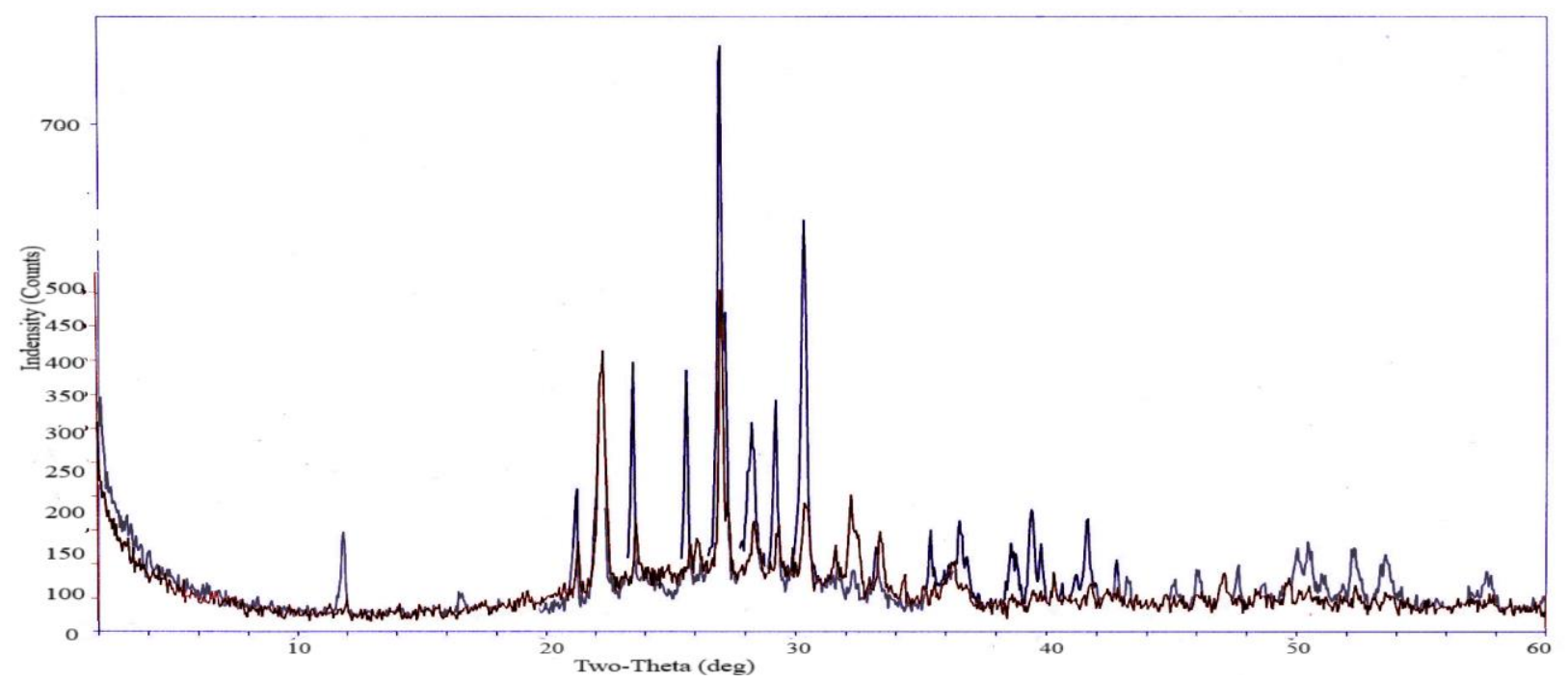

Şekil 9. $1150^{\circ} \mathrm{C}$ 'de sinterlenmiş $\mathrm{Al}$ karışımının $\mathrm{BPO}_{4}$ katkılı ve katkısız XRD kırınım desenlerinin karşılaş̧tırılması. 


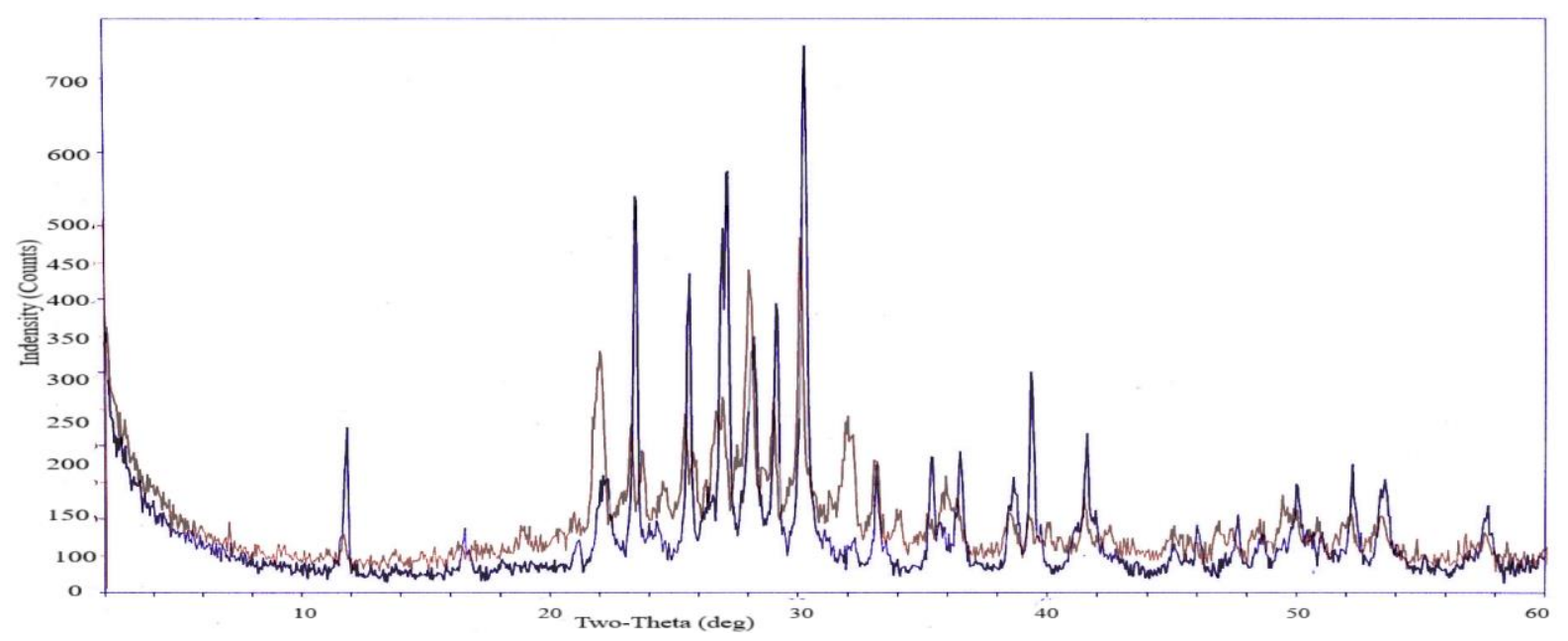

Şekil 10. $1100^{\circ} \mathrm{C}$ 'de sinterlenmiş $\mathrm{A} 2$ karışımının $\mathrm{BPO}_{4}$ katkılı ve katkısı XRD kurınım desenlerinin karşılaştırılması.

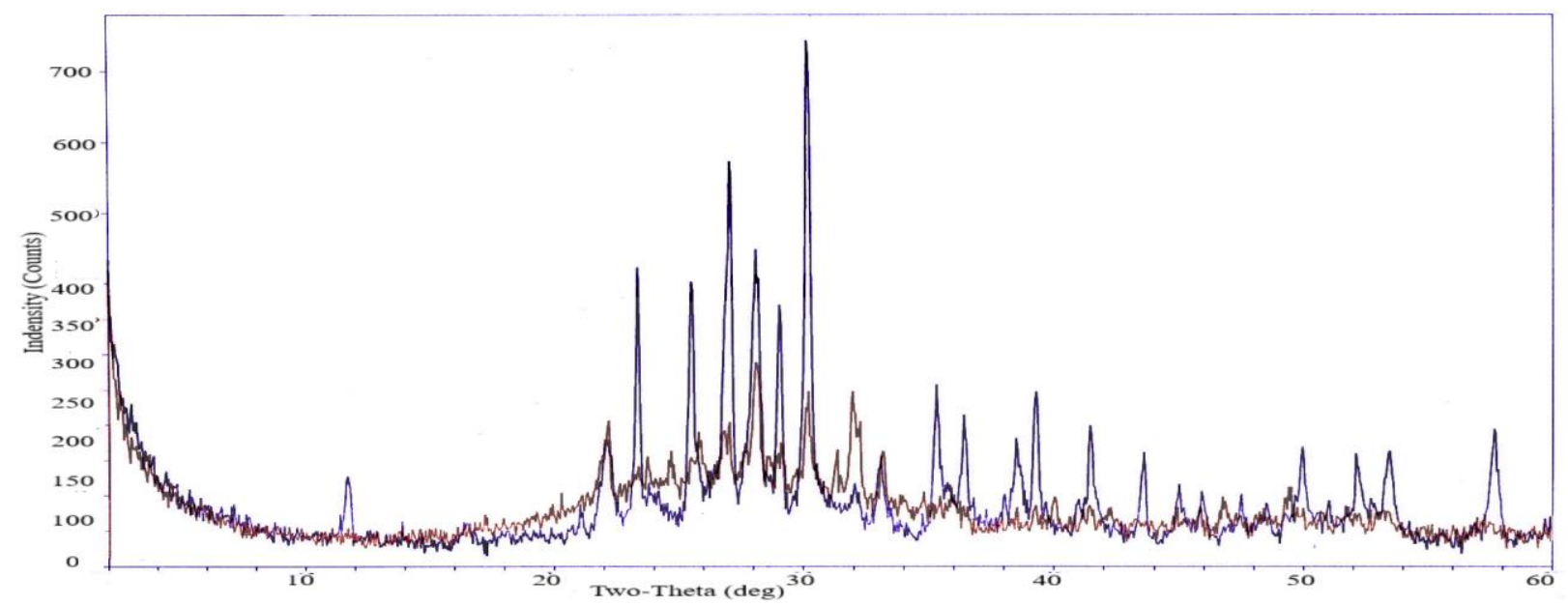

Şekil 11. $1150^{\circ} \mathrm{C}$ 'de sinterlenmiş $\mathrm{A} 2$ karışımının $\mathrm{BPO}_{4}$ katkılı ve katkısı XRD kurınım desenlerinin karşılaş̧tırılmast.

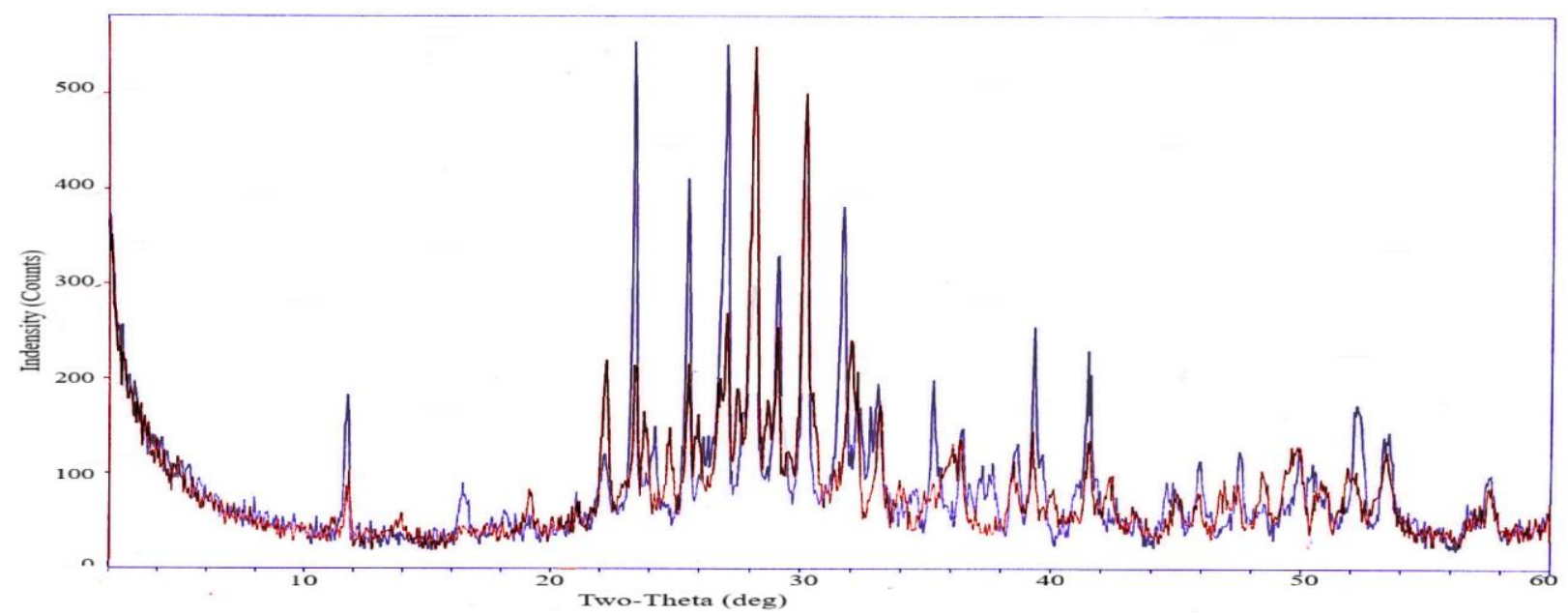

Şekil 12. $1100^{\circ} \mathrm{C}^{\prime}$ de sinterlenmiş $\mathrm{A} 3$ karışımının $\mathrm{BPO}_{4}$ katkılı ve katkısız XRD kırınım desenlerinin karşılaştırılması. 


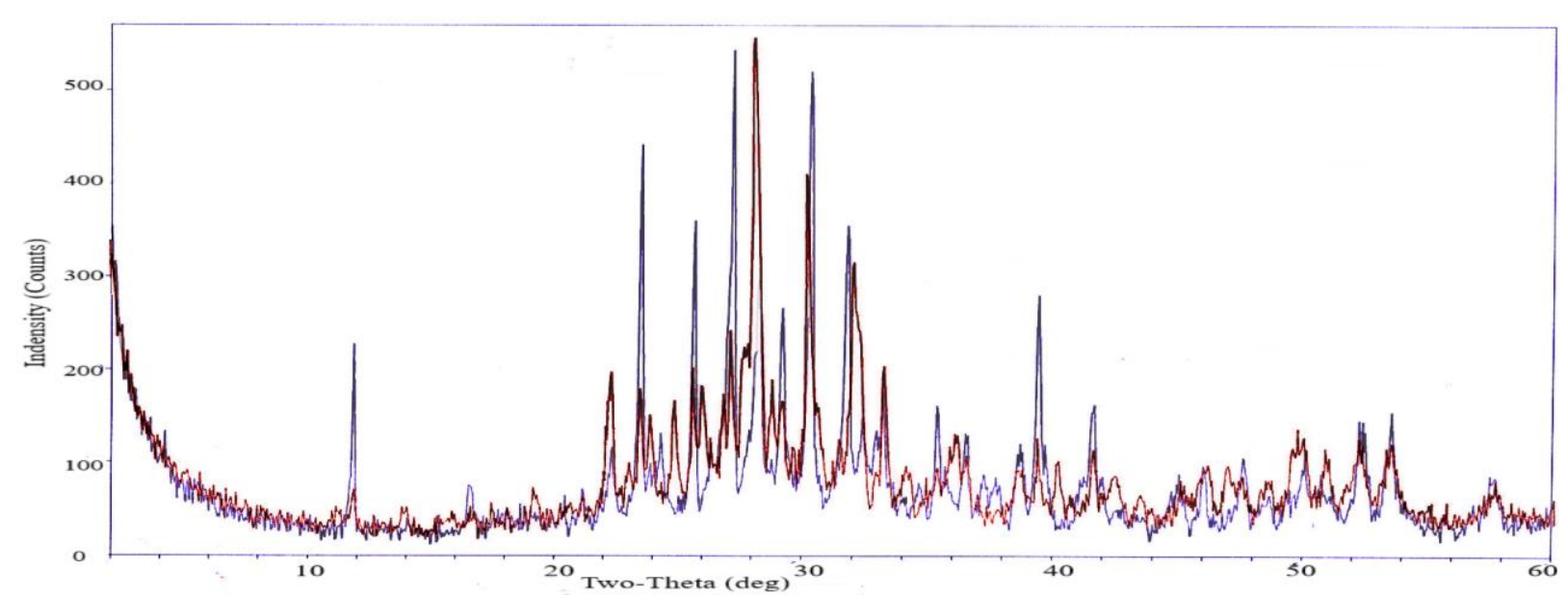

Şekil 13. $1150^{\circ} \mathrm{C}$ 'de sinterlenmiş $\mathrm{A} 3$ karışımının $\mathrm{BPO}_{4}$ katkılı ve katkısı XRD kırınım desenlerinin karşılaştırılması.

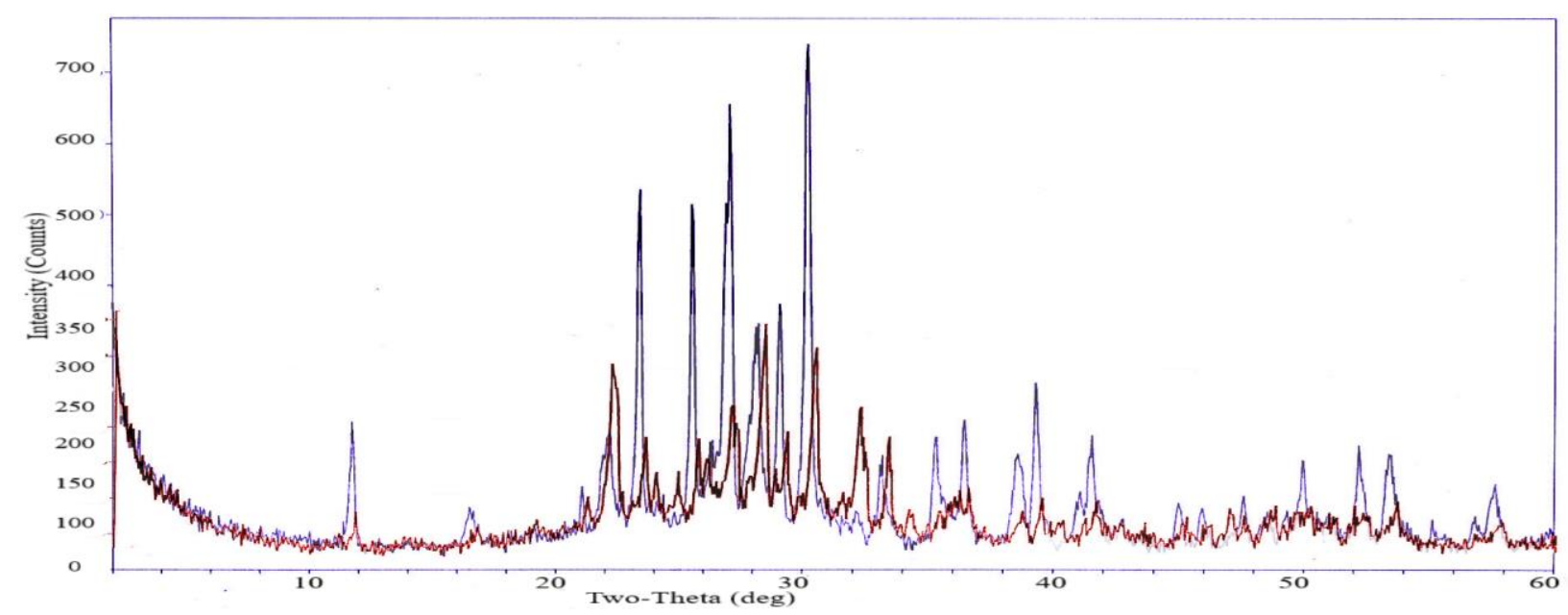

Şekil 14. $1100^{\circ} \mathrm{C}$ 'de sinterlenmiş $A 4$ karışımının $\mathrm{BPO}_{4}$ katkılı ve katkısı XRD kırınım desenlerinin karşıllaştırılması.

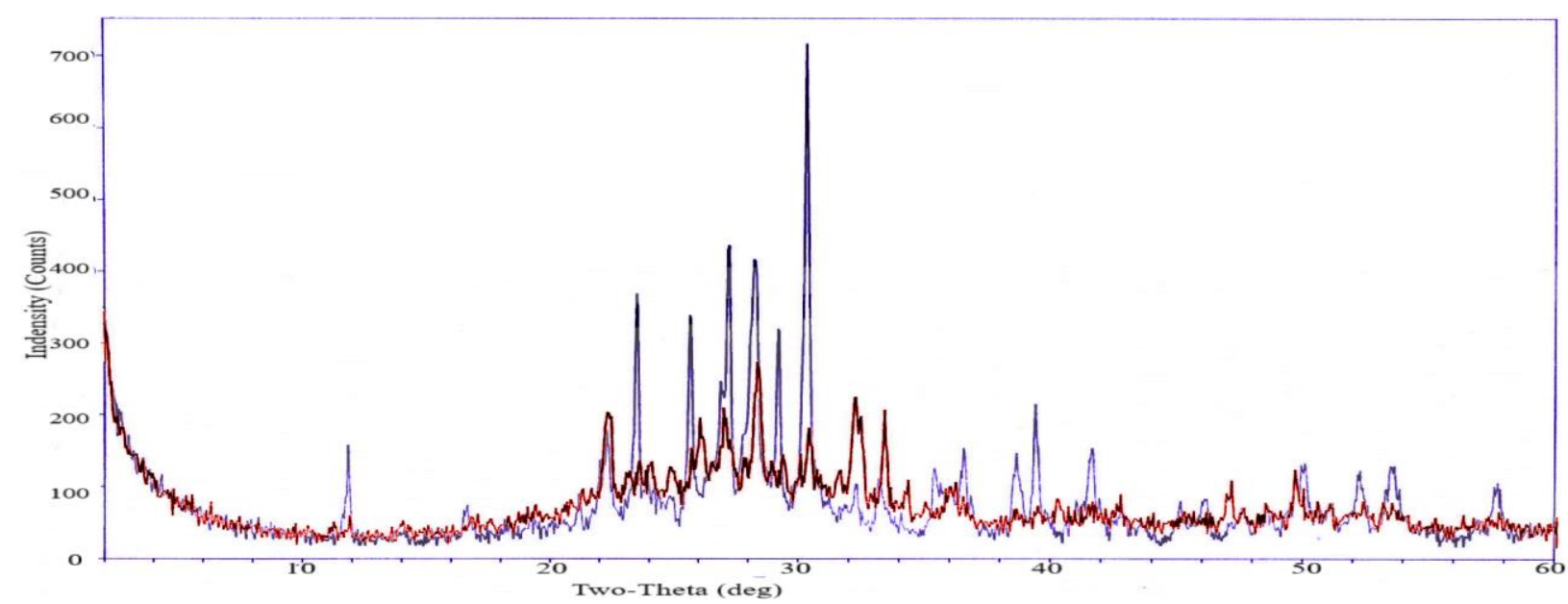

Şekil 15. $1150^{\circ} \mathrm{C}^{\prime}$ de sinterlenmiş $\mathrm{A} 4$ karışımı nın $\mathrm{BPO}_{4}$ katkılı ve katkısız XRD kırınım desenlerinin karşılaş̧tırlmast. 


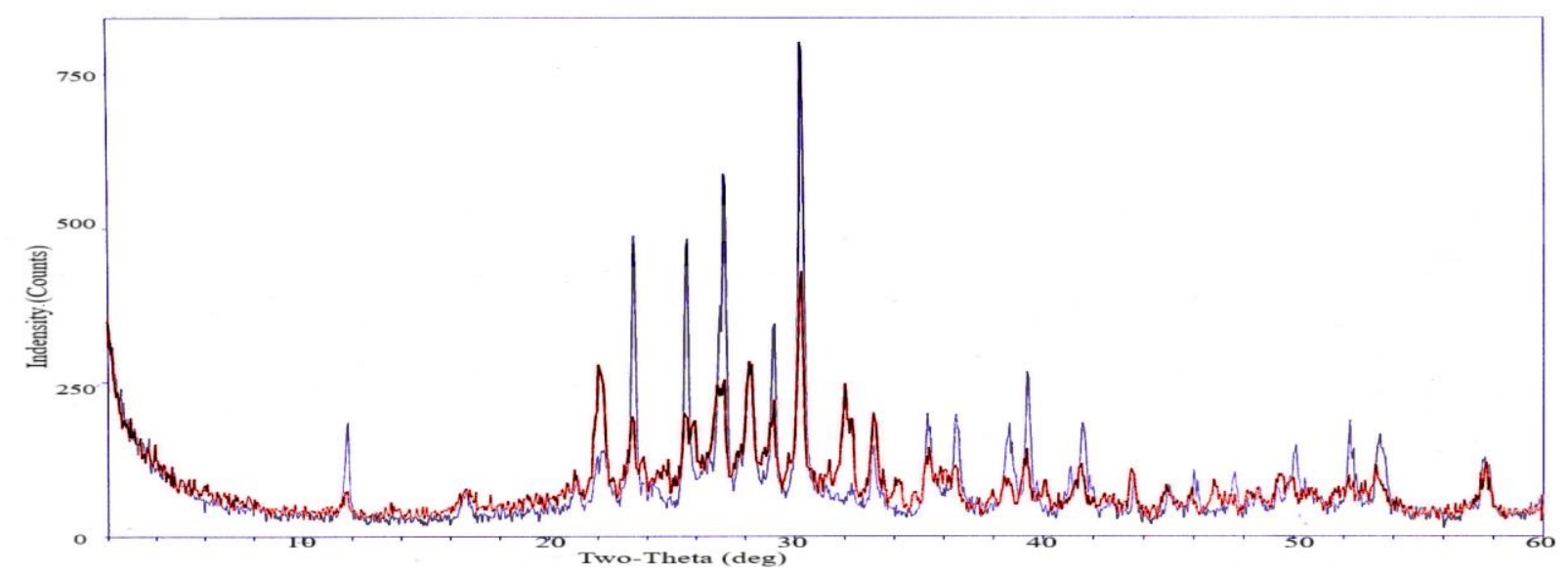

Şekil 16. $1100^{\circ} \mathrm{C}$ 'de sinterlenmiş $\mathrm{A} 5$ karışımının $\mathrm{BPO}_{4}$ katkılı ve katkısı XRD kırınım desenlerinin karşılaştırılması.

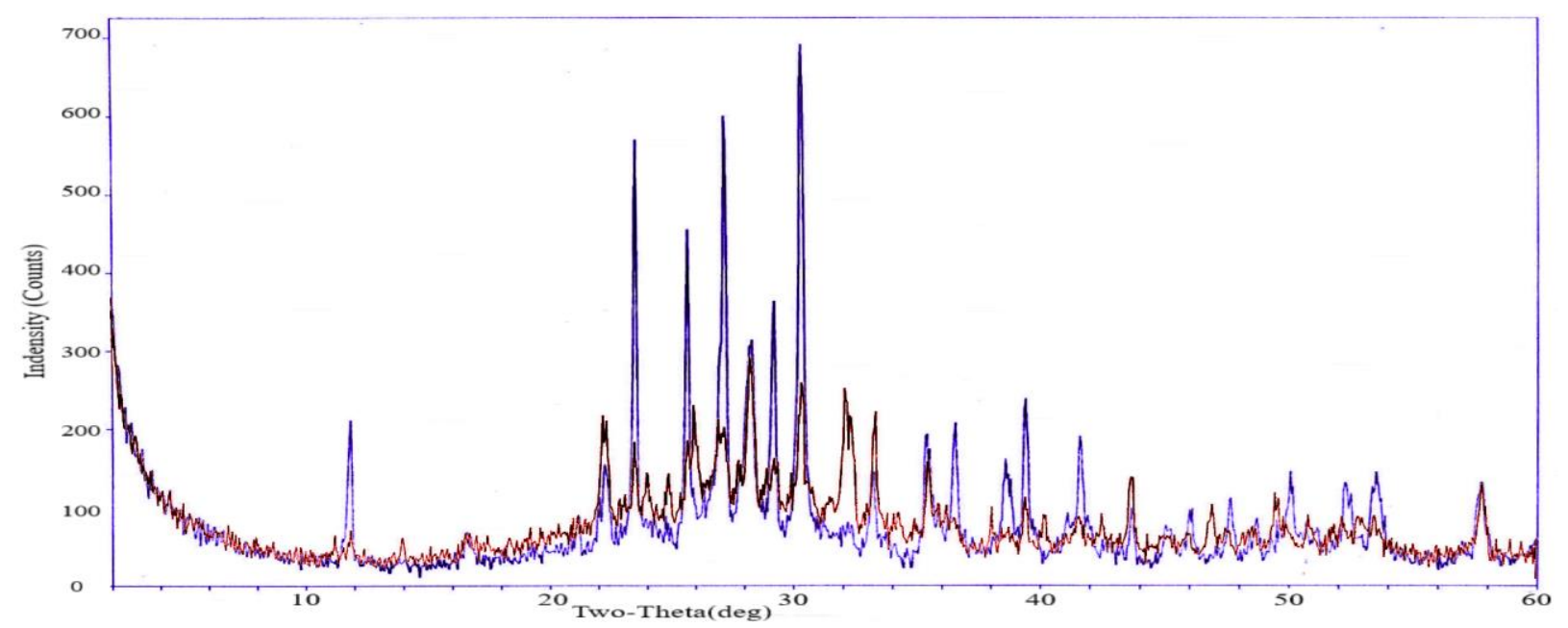

Şekil 17. $1150^{\circ} \mathrm{C}$ 'de sinterlenmiş $\mathrm{A} 5$ karışımının $\mathrm{BPO}_{4}$ katkılı ve katkısı XRD kırınım desenlerinin karşılaştırılması.

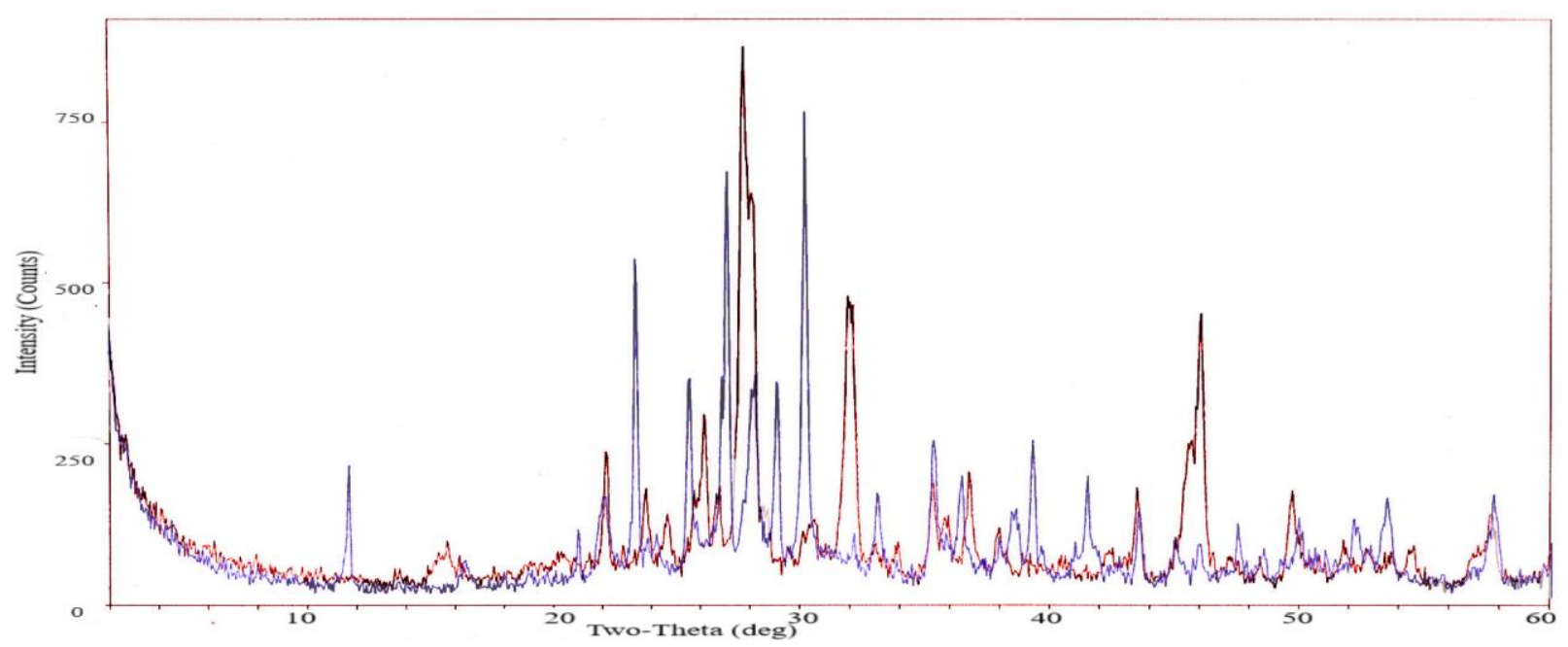

Şekil 18. $1100^{\circ} \mathrm{C}$ 'de sinterlenmiş $\mathrm{A} 6$ karışımının $\mathrm{BPO}_{4}$ katkılı ve katkısız XRD kırınım desenlerinin karşılaştırılması. 


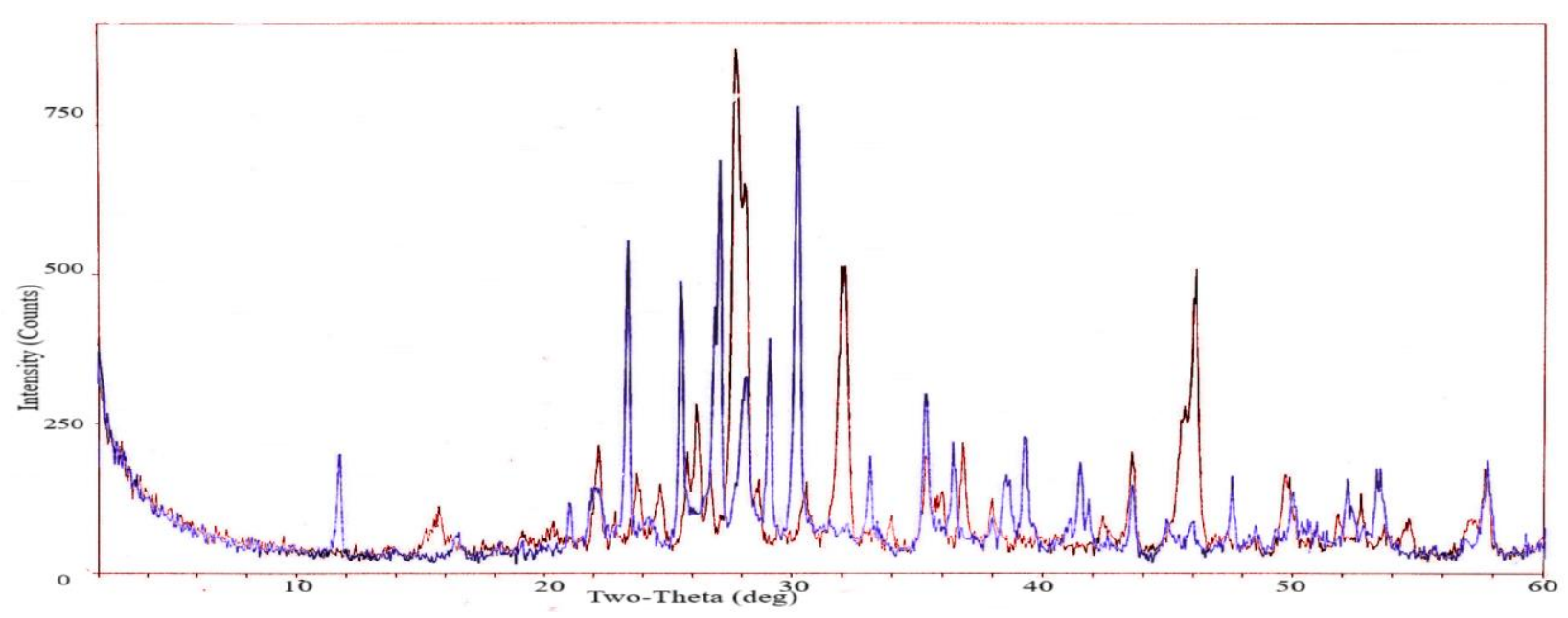

Şekil 19. $1150^{\circ} \mathrm{C}$ 'de sinterlenmiş $\mathrm{A} 6$ karışımının $\mathrm{BPO}_{4}$ katkılı ve katkısı XRD kırınım desenlerinin karşılaş̧tırlması.

XRD analizlerinde bor fosfat katkısı olan bünyelerde camsı faz miktarlarında artış olduğu görülmektedir. Borik asit ilavesi ile yapılan çalışma da benzer sonuçlar elde edilmiş ve XRD analizlerinde tespit edilen kalıntının kuvars da kullanılan kilden geldiği tespit edilmiştir [7].

\section{SONUÇ VE ÖNERILLER (CONCLUSIONS AND RECOMMENDATIONS)}

$\mathrm{Bu}$ çalışmada borik asit ve fosforik asitin stokiyometrik oranda 1sıtılarak karıştırılması sonucu bor fosfat elde edilmiştir. Elde edilen bor fosfatın X-Işınları kırınımı desenleri ile bor fosfatın ASTM standart XIşını kırınım değerleri karşılaştırılmış ve büyük oranda birbirine benzediği ve eşleştiği belirlenmiştir. Yapılan kimyasal analiz sonucunda ise $\% \mathrm{~B}_{2} \mathrm{O}_{3}$ miktarının stokiyometrik olarak teorik olarak hesaplanandan daha büyük olduğu görülmüştür. Bu çalışmada kullanılan fosforik asidin ticari olması ve satılan bu ürünün saflığının belirtilen saflıkta olmaması stokiyometrik oranların değişmesine yol açabilir.

$\mathrm{Bu}$ çalışmada seçilen hammaddelerin teorik saflıkta olduğu varsayılarak hesaplamalar yapılmıştır. Hammaddelerin kimyasal analizleri teorik saflıkta olmadığını göstermektedir. Bu da oluşan anortit fazlarının miktarında azalmaya neden olmaktadır. X Işını kırınımı analizinde pik şiddetlerinin azalmasına sebep olmaktadır.

Vollastonit, kaolinit, kalsit ve kuartz hammaddeleri kullanılarak oluşturulan anortit karışımları $1100^{\circ} \mathrm{C}$ 'dan başlayarak $1150,1200,1250^{\circ} \mathrm{C}$ 'lara pişirilmiştir. Pişirilen örneklere yapılan X-Işını kırınımı analizi sonucu teorik olarak $1150^{\circ} \mathrm{C}$ da oluşması gereken anortit fazının $1100^{\circ} \mathrm{C}$ da oluştuğu belirlenmiştir. $\mathrm{Bu}$ sonuçlara göre bor fosfat anortit fazlarının oluşum sıcaklıklarını daha da azalttığı belirlenmiştir. $\mathrm{BaCu}\left(\mathrm{B}_{2} \mathrm{O}_{5}\right)$ katkısının \%5'lik ilavesi ile yapılmış çalışmada da katkı maddesi sinterleşme sıcaklığını düşürmüştür [9]. Yine $\mathrm{CuF}_{2}$ katkısı ile yapılan çalışmada sinterleşme sıcaklığ $1100^{\circ} \mathrm{C}^{\prime}$ dan $950^{\circ} \mathrm{C}$ 'a düşürülmüştür $[10]$.

Sıvı faz sinterlenmesinde ilk sıvının düşük sıcaklıkta oluşması ve sinterlenecek tanecikleri 1slatması (1slatma açısının $45^{\circ}$, den küçük olması) gerekmektedir [11]. Bor fosfat şişme olmadan bu iki görevi de yerine getirdiği faz diyagramlarından anlaşılmaktadır. Bor fosfat yüksek sicaklıklarda $\mathrm{B}_{2} \mathrm{O}_{3}, \mathrm{P}_{2} \mathrm{O}_{5}$ oluşturur ve bu oksitlerin anortit oluşturan $\mathrm{CaO}, \mathrm{Al}_{2} \mathrm{O}_{3}, \mathrm{SiO}_{2}$ ile yaptığı faz diyagramları ve oluşturdukları ötektikler, karışımların düşük sıcaklıklarda oluşacağının göstergeleridir. Bor fosfatın anortitle yaptığı faz diyagramlarını çalışmak ilerde yapılacak çalışmalara ışık tutacaktır.

Karışımlara uygulanan DTA ve TGA eğrileri $1100^{\circ} \mathrm{C}$ a kadar alınabilmiştir. Tam fazların ortaya çıkma aşamasında DTA cihazının sınır sıcaklığına gelinmiş gerekli pikler çok açık olarak görülememiştir. Fazların oluştuğu sıcaklıklarda ekzotermik piklerin çok geniş olması ve çok küçük olması da bu durumun 
ortaya çıkmasında etkili olmuştur. Ayrıca 1sıtma hızının daha küçük seçilmesi ve DTA cihazının hassasiyeti ve sıcaklık aralığının arttırılması bu sorunu giderecektir.

\section{SEMBOLLER}

$\mathrm{d}$

$\theta$

$\lambda$

I/Io
Düzlemler arası mesafe

Değme (difraksiyon) açısı

Dalga boyu

Difraksiyon çizgilerinin şiddeti

\section{KAYNAKLAR (REFERENCES)}

[1] Gang L., Jing Y., Rui N., Laiming J., Zhi T., Jianguo Z., Qiang C., "Electrical properties and thermal stability of Ce-modified Ca0.80( $\mathrm{Li} 0.5 \mathrm{Bi} 0.5) 0.20 \mathrm{Bi} 2 \mathrm{Nb} 2 \mathrm{O} 9$ ceramics", Journal of Alloys and Compounds, 697 (2017), 380-387.

[2] Dondi, M., Ercolani, G., Melandri, C., Mingazzini, C. and Marsigli, M., "The chemical composition of porcelain stoneware tiles and its influence on microstructural and mechanical properties" Interceram, $1999,75-83$.

[3] Kurczyk, H.G., “Advances in Ceramics Processing”, National Research Council, Foenza, 1977, 172199.

[4] Qin J., Cui C., Cui X., Hussain A., Yang C., Yang S., "Recycling of lime mud and fly ash for fabrication of anorthite ceramic at low sintering temperature", Ceramics International, 41 (2015), 56485655.

[5] Pena, G., Diaz, C.C., Alvarez, D. "Energy and Ceramics" Elsevier Screntific Pub. Amsterdam, 1980, 245-266.

[6] Sletson, L.C., Reed. J.S. "Microstructure Development in a Vitrified Anorthite Porcelain" Ceramic Soc. Bull., 1988, 67 (8), 1403-1408.

[7] Aydın T., Kra A., "Borik Asit İlavesinin Elektroporselen Bünyelerin Sinterleme Davranışları Üzerine Etkisinin İncelenmesi”, 2. Uluslararası Katılımlı VII. Seramik Kongresi, Afyonkarahisar/Türkiye ISBN: 978-975-7150-90-9, 26-28, 2008.

[8] Beals, R.J., Cook, R.L., "Low expansion cordierite porcelains", J.Am.Cer.Soc., Cilt 2, No 35, 1952, 53-57.

[9] Zixuan F., Bin T., Feng S., Shuren Z., "Low temperature sintering of high permittivity Ca-Li-Nd-Ti microwave dielectric ceramics with $\mathrm{BaCu}\left(\mathrm{B}_{2} \mathrm{O}_{5}\right)$ additives", Journal of Alloys and Compounds, 693 (2017), 843-852.

[10] Chung M. W., Cheng C. T., Jyh S., Cheng S. H., Sheng Y. C., Zong Y. C., Hsiu H. S., "Lowtemperature-sintered CuF2-doped NKN ceramics with excellent piezoelectric and dielectric properties", Journal of Alloys and Compounds, 698 (2017), 1028-1037.

[11] Abdullah D. P., "Kaolinitik Bir Kilin Sinterleşme Özelliklerinin İncelenmesi”, Yüksek Lisans Tezi, Ankara Üniversitesi Fen Bilimleri Enstitüsü Kimya Anabilim Dalı, 2008. 